\author{
Monika Nawrot-Borowska \\ Uniwersytet Kazimierza Wielkiego w Bydgoszczy \\ Zaktad Teorii Wychowania i Deontologii Nauczycielskiej \\ Instytut Pedagogiki
}

\title{
Zabawy dzieci ziemiańskich $w$ drugiej połowie XIX i na początku wieku XX w świetle pamiętnikarstwa
}

\begin{abstract}
Games of landowning children in the in the second half of XIXth and at the beginning of XXth century in the light of the memories

The aim of this article is to show the playground of children from landowning families during the second half of the nineteenth and the early twentieth century. An attempt was made to present the playgrounds of wealthy children, their characteristics, space, and also to determine the place and role of play in the lives of children of landowners. The types of games for children, both boys and girls have been presented. Also children's toys were made the subject of research. The conclusions presented have been based entirely on the analyses of diaries, memoirs and biographies of the representatives of landowning class.
\end{abstract}

Keywords: games, fun, toys, childhood, gentry, memories, second-half of the 19th century, beginning of the 20th century

Zjawisko ludyzmu jest od dawna przedmiotem badań wielu naukowców, m.in. kulturoznawców, etnografów, socjologów, historyków, psychologów i pedagogów. W literaturze istnieje więc wiele ujęć definicyjnych pojęcia zabawy. Złożoność tego zajęcia, różnorodność rodzajów i form zabaw, wielość funkcji i zastosowań w poszczególnych okresach życia ludzkiego powoduje, iż trudno jest odnaleźć pełną i jednoznaczną definicję czy klasyfikację tej działalności człowieka ${ }^{1}$. W badaniach historyczno-pedagogicznych w ostatnich latach szczególnie daje się zauważyć zainteresowanie problematyką zabaw dziecinnych, które są istotnym elementem badań nad dzieckiem i dzieciństwem w róż-

\footnotetext{
${ }^{1}$ Dokładną analizę różnorodnych ujęć definicyjnych zabawy, z uwzględnieniem klasyfikacji zabaw zarówno w okresie dzieciństwa, jak i w dorosłym życiu podają np.: J. Huizinga, Homo ludens. Zabawa jako źródło kultury, Warszawa 1985, s. 11-19; J. Cieślikowski, Wielka zabawa, Wrocław 1985, s. 214-219; W. Okoń, Zabawa a rzeczywistość, Warszawa 1987, s. 10-24; J. Grad, Zabawa - analiza pojęć i koncepcji, „Zabawy i Zabawki”, Kwartalnik poświęcony zagadnieniom ludyzmu i ludyczności, nr 1-2, Kielce 1997, s. 7-19; J. Truskolaska, Osoba i zabawa, Elementy filozofii i pedagogiki zabawy, Lublin 2007, s. 63-67.
} 
nych epokach historycznych ${ }^{2}$. Celem niniejszego artykułu jest ukazanie zabaw dzieci z rodzin ziemiańskich okresie II połowy XIX i początków XX w. Dokonano próby prezentacji bogactwa zabaw dziecięcych, ich specyfiki, przestrzeni, a także określenia miejsca i roli zabawy w życiu dziecka ziemiańskiego. Prezentowane wnioski oparto w całości na analizie materiałów pamiętnikarskich, wspomnień i biografii ${ }^{3}$ przedstawicieli warstwy ziemiańskiej, czy też (w literaturze często używa się tego terminu zamiennie) szlachecko-ziemiańskiej ${ }^{4}$.

${ }^{2}$ Patrz np.: K. Kabacińska, Zabawy i zabawki w osiemnastowiecznej Polsce, Poznań 2007; eadem: W co i jak bawity się polskie dzieci w XVIII wieku?, w: Dziecko w rodzinie i społeczeństwie. Dzieje nowożytne, red. K. Jakubiak, W. Jamrożek, Bydgoszcz 2002, t. II, s. 87-100; eadem, Zabawy i zabawki dziecięce w czasopiśmiennictwie dziewiętnastowiecznym na przykładzie „Kroniki Rodzinnej”, w: Czasopiśmiennictwo XIX i poczatków XX wieku jako źródło do historii edukacji, red. I. Michalska, G. Michalski, Łódź 2010, s. 147-158; R. Kantor, R. Zięzio, Zabawy i zabawki w życiu polskich dzieci w XIX i XX wieku, w: Od narodzin do wieku dojrzatego. Dzieci i młodzież w Polsce, część II - stulecie XIX i XX, red. E. Mazur, Warszawa 2003, s. 247-260; B. Pilichowska, Zabawy i zabawki chłopięce w XIX-wiecznym Krakowie, „Zabawy i Zabawki” 1997, nr 1-2, s. 63-76; Zabawy i zabawki, w: A. Bołdyrew, Matka i dziecko rodzinie polskiej. Ewolucja modelu życia rodzinnego w latach 1795-1918, Warszawa 2008, s. 152-156; Zabawy i zabawki, w: A. Pachocka, Dzieciństwo we dworze szlacheckim w I połowie XIX wieku, Kraków 2009, s. 189-209; Dawne zabawy dziecięce, red. D. Żołądź-Strzelczyk, K. Kabacińska, Kielce-Warszawa 2008; Dawne i współczesne zabawki dziecięce, red. D. Żołądź-Strzelczyk, K. Kabacińska, Poznań 2010; M. Nawrot-Borowska, Zabawy dzieci polskich w drugiej połowie XIX $i$ na poczatku XX wieku w świetle zapatrywań teoretycznych, w: Prace Katedry Historii Edukacji $i$ Wychowania w Rodzinie, t. 2: Kultura, edukacja, rodzina, gender studies. Antyk - Polska, red. B. Stawoska-Jundziłł, Bydgoszcz 2011, s. 195-220; eadem, Zabawy dzieci na wsi polskiej w II połowie XIX i na poczqtku XX wieku w świetle literatury pamiętnikarskiej, „Przegląd Pedagogiczny” 2011, nr 2.

${ }^{3} \mathrm{Na}$ potrzeby niniejszego tekstu analizie poddano 110 pamiętników, których autorzy pochodzili z rodzin szlachecko-ziemiańskich i okres swojego dzieciństwa spędzali na ternie zaboru rosyjskiego. W 59 z analizowanych wspomnień znajdowały się bardziej lub mniej obszerne wzmianki na temat zabaw dziecięcych. Liczba ta nie jest z pewnością reprezentatywna dla całej warstwy rodzin szlachecko-ziemiańskich, a badania niniejsze stanowią jedynie przyczynek do rozpatrywanego zagadnienia, i wymagają dalszych i pogłębionych analiz; Patrz np.: J. Deresiewicz, Uwagi o pamiętnikach jako źródle historycznym, w: „Pamiętnikarstwo Polskie” 1976, nr 1-4; F. Jakubczak, Metodologiczne problemy użytkowania pamiętników, w: Ruch pamiętnikarski i przemiany kultury polskiej, red. Z. Krzemień, Warszawa 1972; B. Matus, Bez pamiętników nie ma historii, w: Pót wieku pamiętnikarstwa, wybór i oprac. S. Adamczyk, S. Dyksiński, F. Jakubczak, Warszawa 1971; R. Lubas-Bartoszyńska, Style wypowiedzi pamiętnikarskiej, Kraków 1983; A. Kicowska, Pamiętniki jako źródło badań nad dzieckiem i dzieciństwem, w: Dziecko w rodzinie i społeczeństwie. Dzieje nowożytne, red. K. Jakubiak, W. Jamrożek, Bydgoszcz 2002; Z. Wojtkowiak, Nauki pomocnicze historii najnowszej. Źródłoznawstwo. Źródła narracyjne - pamiętnik, tekst literacki, Poznań 2003.

${ }^{4}$ Ziemiaństwo rozumiane jest tutaj jako warstwa własicieli dużych posiadłości ziemskich, gospodarstw folwarcznych, dziedziców, obszarników, ale też jako szlachecka elita, szeroka warstwa społeczno-kulturowa, dla której dwór i ziemia stanowią bazę materialną, rodzinną i obyczajową, za: Ziemiaństwo polskie 1975-1945. Zbiór prac pod red. J. Leskiewiczowej, Warszawa 1985, s. 13; Warstwa szlachecko-ziemiańska była zróżnicowana, głównie w zależności od posiadanego majątku. Ryszarda Czerpulis, analizując uwarstwienie społeczne Królestwa Polskiego w świadomości ówczesnych rozróżnia warstwę szlachecką na dwie podgrupy - obywateli ziemskich, czyli szlachtę właściwą (byli to ludzie, którzy zachowali cechy właściwe dawnej szlachcie, tj. byli urodzeni w tym stanie, utrzymywali dziedziczne dobra ziemskie, jednocześnie nie używając tytułów honorowych), oraz drobną szlachtę (ludzie pochodzenia szlacheckiego, którzy zachowali drobną własność ziemską oraz ci, którzy straciwszy niezależną pozycję, pozostali przy zajęciach rolniczych; byli to zarówno właściciele niewielkich działek, jak i dzierżawcy czy rządcy cudzych majątków), za: R. Czerpulis, Uwarstwienie społeczne Królestwa w świadomości współczesnych, w: Społeczeństwo Królestwa Polskiego. Studia o uwarstwieniu i ruchliwości społecznej, red. W. Kula, Warszawa 1968, s. 187, 198; patrz też: J. Leskiewiczowa, I. Rychlikowa, Ziemiaństwo. Stan czy klasa. Liczebność ziemiaństwa, w: Przemiany społeczne w Królestwie Polskim 1815-1864, Wrocław 1979, s. 371-387; Dwór polski w XIX wieku. Zjawisko historyczne i kulturowe, 
Sięganie do przeszłości nie jest tylko przywilejem najstarszego pokolenia. To właśnie dzięki temu wspaniałomyślnemu dzieleniu się swoja wiedza, przeżyciami i refleksjami nad swoim życiem, a także innych ludzi, dokonuje się niezwykle ważny przekaz dziedzictwa kulturowego pomiędzy generacjami. Dzieje krajów, narodów czy choćby pewnych grup osób widziane przez pryzmat osobistych doświadczeń mogq stać się dla młodszych pokoleń nie tylko sucha, naukowq informacja, ale żywq i barwnq historia, w której uczestniczyli konkretni ludzie $e^{5}$ czytamy we wstępie wspomnień Andrzeja Kownackiego. Tak właśnie jest z pamiętnikami, będącymi podstawą źródłową niniejszego tekstu. Ich autorzy, których życie uwikłane było w czasy powstań narodowych, rewolucji, wojen światowych, sięgają pamięcią nie tylko do tych znaczących i historycznych wydarzeń, ale opisują perypetie swoje i swoich rodzin, radości i smutki dnia codziennego, tradycje, zwyczaje i obyczaje czasów, w których przyszło im żyć. Nakreślają własne losy na tle wydarzeń politycznych, społecznych, obyczajowych. Okres dzieciństwa we wspomnieniach stanowi często skromną ich część, czy to z racji słabej pamięci, czy przekonania o małej istotności tego okresu w porównaniu z pozostałymi okresami życia. Jednak bywają pamiętnikarze, którzy barwnie i bogato opisują swoje najmłodsze lata, a niektórzy z nich poświęcają temu okresowi osobne rozdziały czy nawet tomy wspomnień. Otwórzmy więc strony pamiętników i cofnijmy się do przeszłości sprzed ponad 100, a nawet 150 lat, pozwólmy, by beztroskie chwile zabawy dzieci z rodzin ziemiańskich znowu ożyły w przytaczanych tu cytatach i fragmentach wspomnień.

Na rodzaje, przebieg i organizację zabaw dziecięcych wpływ miało wiele czynników. Wskazać należy m.in. wiek i płeć dzieci, miejsce zabawy, porę roku, pogodę, towarzystwo rodzeństwa, rówieśników lub dorosłych - rodziców, innych członków rodziny czy służby, posiadane zabawki, a także indywidualne zainteresowania dzieci, ich fantazja i pomysłowość.

Dla organizacji zabaw dziecięcych ogromne znaczenie miała przestrzeń dworu. Nie ograniczała się ona oczywiście jedynie do wnętrza domu, a więc przedpokoi, pokoi, salonów, bawialni, gabinetów, sypialni, jadalni, korytarzy, kuchni, kredensów, schodów, strychów, które stanowiły niezwykle bogate zaplecze dla dziecięcej fantazji ${ }^{6}$, ale składa-

red. J. Baranowski, Warszawa 1992; T. Krawczak, W szlacheckim zaścianku, Warszawa-Siedlce 1993; Dziedzictwo. Ziemianie polscy i ich udział w życiu narodu, Kraków1995; Polska kultura ziemiańska. Szkice i rozprawy, red. E. Kosowska, Katowice 1995; S. Rudnicki, Ziemiaństwo, w: Społeczeństwo polskie w XX wieku, red. J. Żarnowski, Warszawa 2003, s. 205-260; M. Łozińska, W ziemiańskim dworze. Codzienność, obyczaje, święta, zabawy, Warszawa 2010.

5 A. Kownacki, Czy było warto? Wspomnienia, oprac., wstęp i przypisy R. Stopikowski, przedmowa ks. Z. Zieliński, Lublin 2000, s. 11.

${ }_{6}$ Jarosław Iwaszkiewicz bardzo obszernie charakteryzuje przestrzeń dworu, poświęcając opisowi kilkanaście stron swoich wspomnień: To stare domostwo, niskie i o grubych murach [...] było zaczarowanym pałacem mojego dzieciństwa. Wydawało mi się ogromne i miejscami tajemnicze. Na prawo z sieni wchodziło się do salonu, nigdy prawie nie używanego, gdzie stały stare meble [...] na lewo byt pokój stołowy, centrum całego życia [...] W stołowym stał olbrzymi stół przykryty żólta ceratq - proporcje całego domu, otoczenia, ogrodu wydawaty mi się wtedy tak duże [...] W stołowym pokoju przed piecem w rogu widniat jak gdyby duży próg ceglany, stół jakiś, do kładzenia drzewa. Ten rodzaj stołu był dla mnie miejscem ukochanych zabaw [...] Widok obszerny rozciagat się z nastęnego pokoju za jadalnia, pokoju mojej najstarszej siostry Heleny, z którym zwiqzane sq u mnie bardzo liczne wspomnienia [...] W tym też pokoju spędzałem dtugie zmierzchy letnie czy 
ło się też na nią całe dworskie otoczenie bliższe i dalsze. Dworskie ogrody, parki, oficyny, przybudówki, stajnie, obory, chlewy, drwalnie, mleczarnie, kuźnie, obudowane stodołami podwórza, czworaki, kurniki, gołębniki, sady, stawy i groble, ścieżki i drogi rozchodzące się na okoliczne pola, lasy i łąki, a nawet rodzinne cmentarze. Władysław Jan Grabski wspominał dwór w Borowie, w którym w początku XX w. mieszkał, opisując przestrzeń swego dzieciństwa - dom oraz [...] zrośnięty z dworem kompleks zabudowań tak obszerny, że obiec go dookoła jednym tchem dziecko by nie zdołało, a zwiedzani spacerem dostarczało tylu spostrzeżeń i przygód, że wypetniało czas od pierwszego śniadania do dzwonu na obiad'. Jednak nie wszystkie te miejsca zawsze dostępne były dla najmłodszych. Ograniczeniem przestrzeni zabawy był oczywiście wiek i nadopiekuńcze często matki czy opiekunki. Najmłodsze dzieci bawiły się w domu, parku czy ogrodzie pod opieką mam, niań lub bon ${ }^{8}$. Dopiero, kiedy dzieci wkraczały w wiek szkolny, czyli ok. 7 roku życia (w przypadku chłopców często po postrzyżynach) mogły w miarę swobodnie biegać po terenie obejścia i zabudowań dworskich i odkrywać nowe miejsca i przestrzenie zabawy, których teren poszerzał się z czasem do okolicznych wiosek. Były oczywiście miejsca, które mogły stwarzać pewne niebezpieczeństwa dla dzieci, w których bawić się im nie było wolno, a o których skrzętnie przypominali im dorośli. Także we dworze nie do wszystkich pomieszczeń dzieci mogły bezkarnie wchodzić. Najczęściej zakazane, a tym samym tajemnicze, były pokoje gościnne, salon, gabinet ojca i spiżarnia. Nie trudno się jednak domyślić, że im częściej mówiono o zakazanych miejscach, tym bardziej podsycała się ciekawość dzieci, które zwykle w tajemnicy przed dorosłymi tam właśnie spędzały czas?

Pamiętnikarze wspominają swoje ulubione miejsca zabaw. Np. Melchior Wańkowicz „lubił pasjami” zabawy na strychu, gdzie, szczególnie zimą, polował na zdziczałe koty i dokonywał odkryć, szperając w starych kufrach i skrzyniach ${ }^{10}$. Stefan Krzywoszewski

jesienne w towarzystwie moich sióstr [...], w: J. Iwaszkiewicz, Ksiażka moich wspomnień, Warszawa 1994, S. $10-11$.

7 W. J. Grabski, Blizny dzieciństwa, Warszawa 1971, s. 11, 25; Ignacy Jan Paderewski, opisując majątek na Podolu, we wsi Kuryłówka, gdzie spędził dzieciństwo, wspominał: Było to jedno z najcudowniejszych miejsc na świecie. Mógłbym bez końca opowiadać o tej miejscowości, jej łagodnym i zdrowym klimacie, malowniczym, falistym krajobrazie i bogactwie gleby, w: I. J. Paderewski, Pamiętniki, spisała M. Lawton, Warszawa 1982, s. 17.

${ }^{8}$ Eugeniusz Janiszewski pisał, że jako mały chłopczyk podczas spacerów z piastunką po okolicy tak rozkochał się w przyrodzie, jej kolorach, dźwiękach, że kiedy tylko pilnująca go w ogrodzie niania zasypiała, chłopiec uciekał przez okoliczne łąki do lasu. Po dłuższych wędrówkach wchodził na drzewo i cierpliwie czekał, kiedy cały dwór przybiegnie go szukać - te chwile objawienia, których doznawałam sam na sam z lasem, pozostały mi pamiętne na całe życie - pisał po latach, w: E. Janiszewski, Wspomnienia odessity 1892-1942, Wrocław 1987, s. 31.

9 W. J. Grabski, op. cit., s. 55, 64-65; C. Czarnowski, Strzępy wspomnień. Szkice autobiograficzne, Warszawa 1973, s. 15-16; J. Iwaszkiewicz, op. cit., s. 15.

${ }^{10}$ M. Wańkowicz, Szczenięce lata, Kraków 1987, s. 41; Zofia Szymanowska wspominała swoje zabawy na strychu w początku wieku XX bardzo obszernie: Nadchodzit czas zabaw. Szliśmy gromada na strych. Strych byt obszerny, trochę ciemny $i$ zawalony gratami, trzcinowymi meblami z ogrodu $i$ kuframi. Byty one petne staroświeckich strojów, pamiqutek i odwiecznych roczników „,Kłosów” i „Biesiady Literackiej” [...] Na strychu pachniało miodem, kurzem i ziołami, a słońce rzucało przez okienka jaskrawe stupy światła, w których tańczyt obłakanym wirem gęsty kurz. Strych miat jednq wielkq zaletę: można było przez jedno z jego okienek wydostać 
upodobał sobie obszerny ogród, a szczególnie aleję lipową, gdzie pod najbardziej rozłożystą z nich urządzał sobie zieloną altankę, w której obserwował owady, ptaki i ich pisklęta. Dużo czasu spędzał także na łąkach, polach, nad rzeką i w okolicznych wioskach - mimo że nie miał jeszcze 8 lat. Szczególnie lubił pośród przyrody wypatrywać tajemniczych postaci, o których usłyszał podczas wieczornych opowieści ${ }^{11}$.

Zabawy uzależnione były także od pory roku oraz pogody panującej na zewnątrz. W niektórych dworach, w których praktykowano tzw. wychowanie cieplarniane, nie wypuszczano dzieci z domu zimą aż do Wielkiejnocy, by się nie rozchorowały ${ }^{12}$. W czasie niepogody miejscem przeznaczonym do zabaw dziecięcych we dworze był najczęściej pokój dziecinny lub bawialny. Wielkość pokoju dziecinnego uzależniona była od rozmiarów dworu, lecz zwykle wybierano pokój stosunkowo obszerny, by obok niezbędnych mebli było także miejsce do zabawy. Meble - stoliki, stołki czy krzesła służyły pomysłowym maluchom nie tylko do siedzenia, ale przede wszystkim do zabawy. Wielka narożna kanapa stużyła do robienia niezliczonej ilości koziołków - wspominał Tomasz Zan, którego dziecinny pokój liczył ponad 100 metrów ${ }^{13}$. We wspomnieniach Krystyny Libiszowskiej-Dobrskiej czytamy: Kiedy padat deszcz i musieliśmy zostać w domu, robiliśmy karetę ze stołu nakrytego długim obrusem. Zaprzęgało się do niej sześć rozbrykanych koni, czyli sześć krzeset powiazanych sznurami. O to, żeby konie były rozbrykane, starała się Krysia. Siedzą jak stangret na wysokim kózkę montowanym na dachu karety tak szarpata lejcami, że konie ponosity i przewracaty się na wszystkie strony. My z Henrykiem byliśmy matżeństwem, udajacym się w podróż. Siedzieliśmy pod stołem, dopóki nie następowat wypadek, furman spadat z kozła, ja udawałam zemdlona, wynoszono mnie z kanapy $i$ cucono $^{14}$. Kiedy dzieci było więcej, można było bawić się w zabawy towarzyskie. Należały do nich wymaniane przez pamiętnikarzy: zabawa w czarnego luda, cztery kąty, pierścionek, cenzurowany, szarady i zagadki, fanty, konkurs ustawiania pałaców i domków z talii kart $^{15}$.

się na dach, a stamtąd na szczyt wielkiego orzecha, którego gałęzie kładty się na dachu. Zerwawszy garść najpiękniejszych orzechów ze szczytu, zsuwało się po pniu na ziemię - i już się było w ogrodzie. Była to porywająca sztuka akrobatyczna, którq uprawialiśmy w dzieciństwie z zapałem. W gtębi strychu stał kufer, zawierajacy nasze teatralne przybory, kostiumy, szminki i peruki. Znosiło się to wszystko na dół do pokoju i rozpoczynało sie przebieranie, gorqczkowe szycie i obmyślanie programu zabawy, w: Z. Szymanowska, Opowieść o naszym domu, Warszawa 1980, s. 107.

${ }^{11}$ Tak wspominał swoje chwile beztroski i swawoli: $W$ dżḋyste dni letnie czaiłem się nieraz $w$ gaszczach $w$ daremnej nadziei, że ujrze na łakach płanetnika, spuszczajacego się z chmur na niewidzialnym sznurze. Gdy prażyt skwar, na miedzach, wśród łanów pszenicy, wypatrywaliśmy nie bez lęku Południc, które miaty wygrzewać się w stońcu, w: S. Krzywoszewski, Długie życie. Wspomnienia, t. I, Warszawa 1947, s. 6.

12 Helena Ceysinger, wracając pamięcią do lat dzieciństwa, pisała o fakcie przesadnego chronienia jej przed wszelką wilgocią i chłodem, zamykaniem w pomieszczeniach w celu zapewnienia zdrowia. Dziewczynka z żalem obserwowała wiejskie dzieci, biegające swobodnie niezależnie od pogody. Hodowano mnie jak cieplarnianq roślinę. A tymczasem ten egzotyczny kwiatek wolatby być dzikim chwastem, wybujać swobodnie, pić rosę, słońce i żyć, w: H. Ceysinger, Ze znalezionych kartek, Warszawa 1894, s. 26.

13 W. Wiśniewski, Ostatni z rodu. Rozmowy z Tomaszem Zanem, Warszawa-Paryż 1989, s. 29.

14 K. Libiszowska-Dobrska, Moje złote lata 1913-1939, Warszawa 1997, s. 39.

${ }^{15}$ T. i W. Tatarkiewiczowie, Wspomnienia, Warszawa 1979, s. 35; J. Ostromęcka, Pamiętnik z lat 1862-1911, Warszawa 2004, s. 59; A. Rostworowski, Ziemia, której już nie zobaczysz, Warszawa 2001, s. 25; 
Częstym miejscem zabaw dziecięcych był także pokój bawialny, w którym o szarej godzinie zabierali się zwykle wszyscy domownicy ${ }^{16}$. Jednak im dzieci były starsze, tym chętniej bawiły się w innych pomieszczeniach i różnych zakamarkach dworu. Niektóre z nich, jak np. salon przeznaczone były jednak do przyjmowania gości i organizowania różnych uroczystości i obecność w nich dzieci była raczej niemile widziana ${ }^{17}$.

W domach, w których rodzice dbali o rozwój fizyczny dzieci, w obszernych pokojach dziecinnych zawieszano nie tylko popularne huśtawki, ale dodatkowo także przyrządy do ćwiczeń fizycznych - trapez, kółka, drabinki itp. Tym sposobem dzieci mogły nawet podczas niepogody zażywać ruchu. Kazimierz Andrzej Jaworski opisywał ulubione zabawy na przyrządach - [...] zapamiętawszy niektóre rodzaje ćwiczeń akrobatycznych, stopniowo na mała skale zaczałem je stosować. Podciagatem się więc szybko na trapez, później huśtałem się na nim trzymajac się sznurka jedna ręka, a potem już nie trzymajac się żadna, robiłem mtynek kręcac się zgięta $w$ kolanie noga wokót osi poprzeczki, zawisałem głowa $w$ dół na obu nogach $i$ na jednej. Robiłem też $i$ inne tak zwane sztuczki. Dla bezpieczeństwa nad trapezem rozkładali mi materac, ale $i$ tak nasi znajomi widzac czasami moje popisy chwytali się za głowe [...] Ale rodzice jakoś wierzyli w moje sity, ojciec uważat, że $w$ ten sposób ćwiczę mięśnie $i$ wyrabiam $w$ sobie odwagę ${ }^{18}$.

Dzieci szczególnie lubiły spędzać czas na świeżym powietrzu i tam właśnie organizować sobie najróżniejsze zabawy i zajęcia. Kiedy pogoda dopisywała, wystarczyło wyjść z domu do ogrodu czy parku. W ciepłe wiosenne, letnie czy jesienne dni, kiedy padało, dzieci spędzały także czas na gankach dworów. Często były one wyposażone w stoły, ławki, wiklinowe fotele i zadaszone, co pozwalało miło spędzać tam czas ${ }^{19}$.

Lato było okresem, kiedy dzieci spędzały bardzo dużo czasu na zabawie (choć bywało, że część dnia przeznaczano niekiedy na lekcje domowe). W parkach czy ogrodach pełnych zakamarków, urządzały pola bitew, budowały fortece, mury obronne, domki i huśtawki na drzewach, urządzały kryjówki pośród gałęzi i liści, które pozwalały być niedostrzeżonym, a jednocześnie były doskonałym punktem widokowym na teren dworu. Podczas skakania po gałęziach drzew dzieci (głównie chłopcy) penetrowały ptasie gniazda, podglądały ptaki, wykradały im jajka ${ }^{20}$. Jeśli w okolicy dworu znajdowały się jeziora, rzeki czy stawy, to stawały się one ulubionym miejscem zabaw. Obok kąpieli, skoków do

pamiętnikarze nie opisują zasad tych gier, można jednak zasady ich wszystkich odnaleźć w: Ł. Gołębiowski, Gry i zabawy różnych stanów w kraju całym lub niektórych tylko prowincjach..., Warszawa 1831.

${ }^{16}$ Na wprost od wejścia z przedpokoju, znajdowat się pokój tzw. bawialny, z wygodnymi meblami obitymi wschodnimi kilimami, wielka otomana, kilkoma głębokimi i niskimi fotelami, drugq staroświecka kanapq, stotem, przy którym spędzaliśmy wieczory, gdzie przy stojacej lampie naftowej gromadzili się wszyscy obecni wówczas $w$ domu [...] zacisznie i przytulnie było przy zamkniętych okiennicach, w: T i W. Tatarkiewiczowie, op. cit., s. 30 .

${ }_{17}$ W. J. Grabski, op. cit., s. 17, 62; M. Wańkowicz, op. cit., s. 20-21.

${ }^{18}$ K. A. Jaworski, Wywotywanie cieni, Lublin 1968, s. 26; J. Ostromęcka, op. cit., s. 165.

${ }_{19}$ T i W. Tatarkiewiczowie, op. cit., s. 28; J. z Puttkamerów-Żółtowska, Inne czasy, inni ludzie, Londyn 1959, s. 21.

${ }^{20}$ W. J. Grabski, op. cit., s. 53; A. Kownacki, op. cit., s. 19; E. Ligocki, Dialog z przeszłościq, Warszawa 1970, s. 16; E. Janiszewski, op. cit., s. 31, 70; J. D. Muśnicki, Moje wspomnienia, Warszawa 1935, s. 13; J. z Puttkamerów-Żółtowska, op. cit., s. 66; T. i W. Tatarkiewiczowie, op. cit., s. 31. 
wody, pływania, łowienia ryb, raków, nad wodą działo się wiele ciekawych dla najmłodszych rzeczy - pojono bydło, konie, czerpano wodę, prano itp. Nieco starsze dzieci pływały na łódkach, tratwach ${ }^{21}$.

Letnią porą w ogrodach dojrzewały owoce, którymi można było posilić się po swawolach, zaś samo owocobranie było także okazją do zabaw, wspinania się na drzewa, rzucania owocami do celu itp. W czasie żniw i młócki dzieci przyglądały się pracom polowym i w młockarni, urządzały sobie przejażdżki wozami, chowały się w snopkach zboża. Okoliczne lasy sprzyjały wycieczkom na grzyby, jagody, maliny, poziomki czy orzechy, były świetną okazją do podglądania zwierząt ${ }^{22}$. Podczas żniw zbieraliśmy na rżyskach kłoski, jesieniq szukaliśmy w lesie grzybów i rydzów - wspominał Stefan Krzywoszewski ${ }^{23}$. We wspomnieniach Wacława Sieroszewskiego znajdujemy opis miejsc zabaw letnich, odbywanych z kolegami z kompletu domowej nauki: Po obiedzie mieliśmy czas wolny na zbytki $i$ zabawy $w$ dwóch ogrodach, połaczonych wysadzanych włoskimi topolami aleja. Przy dworze byt cienisty park, obsadzony pięknymi liściastymi drzewami [...] Drugi ogród byt sadem owocowym [...] Do domu blisko przylegat bór sosnowy [...] Mieliśmy tam używanie, zbieraliśmy jagody, grzyby, kopaliśmy rowy, budowali z pisaku domy. Raz nawet wznieśliśmy z wielkim trudem prawdziwa fortecę z piasku, której broniliśmy z zapałałem przed atakami mieszkajacych $w$ sqsiedniej wsi [...] obrzucajac ich szyszkami. Udziat $w$ walkach brali nawet wiejscy chtopcy $[\ldots]^{24}$.

W niektórych dworach, w których rodzice byli zwolennikami harmonijnego rozwoju umysłu i ciała dzieci, urządzano także specjalne place do ćwiczeń fizycznych w ogrodach czy parkach, nazywane potocznie gimnastykami ${ }^{25}$. Instalowano tam huśtawki, trapezy, specjalne drabinki, liny, kołobiegi. Zbudowano nam tzw. gimnastyke - czytamy w pamiętniku Teresy Tatarkiewiczowej - na trawniku postawiono huśtawkę, drabinkę itp., a gdy byliśmy starsi, dodano także kołobieg, który stat się nasza namiętnościa ${ }^{26}$. Zdarza-

${ }^{21}$ M. Wańkowicz, op. cit., s. 44; S. Włoszczewski, Na przełomie dwóch epok, Warszawa 1974, s. 12; S. Kieniewicz, Nad Prypecia, dawno temu...Wspomnienia zamierzchłej przeszłości. Przygotował do druku S. Kieniewicz, Wrocław-Warszawa-Kraków-Gdańsk-Lódź 1989, s. 67; W. Lednicki, Pamiętniki, t. 1, Londyn 1963, s. 499-500; A. Jaroszewicz, Libretto finansisty. Wspomnienia 1881-1947, Warszawa 1968, s. 24, M. Jałowiecki, Na skraju Imperium. Wybór i układ tekstu M. Jałowiecki, Warszawa 2000, op. cit., s. 46; A. Gayer, Z mojego życia. Wspomnienia z lat 1855-1914, Łódź 2002, s. 10; A. Rostworowski, op. cit., s. 24.

22 Z. z Rodowiczów Iwanicka, Pamiętnik, w: W. Rodowicz, S. Rodowiczowa, Z. z Rodowiczów Iwanicka, Tryptyk rodzinny. Dzieje rodziny Rodowiczów, Warszawa 1999, s. 65; C. Czarnowski, op. cit., s. 14; E. Janiszewski, s. 29-31, 70-71; I. J. Paderewski, op. cit., s. 17, 24; S. Kieniewicz, op. cit., s. 67; K. A. Jaworski, op. cit., s. 11; Wspomnienia naszej matki, wyjęte z jej pamiętnika i nasze o barcie Józefie Łukaszewiczu, w: Pierwszy marca 1887 roku. Wspomnienia Józefa Łukaszewicza. Zebrał, przełożył, przedmową i przypisami opatrzył S. Bergman, Warszawa 1981, s. 145; K. Iłłakowiczówna, Wspomnienia i reportaże, Warszawa 1997, s. 93; J. z Puttkamerów-Żółtowska, op. cit., s. 66; T. i W. Tatarkiewiczowie, op. cit., s. 34; Z. Szymanowska, op. cit., s. 105-106.

${ }^{23}$ S. Krzywoszewski, op. cit., s. 6.

24 W. Sieroszewski, Pamiętniki. Wspomnienia, Kraków 1959, s. 23.

${ }^{25}[\ldots]$ jakież to byly mile $i$ wesole lekcje gimnastyki [...] Była w parku na trawie wybudowana duża, $z$ najrozmaitszymi przyborami gimnastyka [...] chłopcy i goście popisywali się zręcznościa, a gdy spadali na trawę, ileż to było śmiechu. Były rozdawane nagrody - czytamy w jednym z pamiętników, w: J. Umiastowska z Ostrorogów, Szmat ziemi i życia ...opisy $i$ wspomnienia, przedmowa C. Jankowski, Wilno 1928, s. 80.

${ }^{26}$ T. i W. Tatarkiewiczowie, op. cit., s. 44. 
ło się też, że na terenie ogrodu wyznaczano miejsca do gier towarzyskich. Młodzi ziemianie wspominają grę w krykieta, polegającą na toczeniu kul pod specjalnymi bramkami, przy użyciu długich młotków, by dotrzeć do palika oznaczającego metę. Gra dostarczała dzieciom sporo emocji, gdyż w jednym z pamiętników czytamy: Żadna chyba gra nie wznieca takich namiętności i rywalizacji [...] kłótnie wybuchały co chwila, lecz przez kilka lat byt to ulubiony sposób wyładowania naszej energii ${ }^{27}$. Pamiętnikarze wspominają także o grze w tenisa, która jednak była domeną młodzieży i dorosłych. Najmłodsi jednak chętnie przyglądali się grze i szukali zagubionych w trawie piłek. Spośród popularnych zabaw na powietrzu autorzy pamiętników wspominają także zabawę w serso (polegającą na toczeniu kółka na kiju, bądź podrzucania go i chwytania), wolanta (z wykorzystaniem korków z przymocowanymi do nich piórkami odbijanych małymi rakietkami), grę w palanta, klipę, chowanego, oraz jazdę na rowerze ${ }^{28}$. Zofia $z$ Rodowiczów-Iwanicka w swoim pamiętniku podkreślała świadomość rodziców w zakresie zdrowego wychowania dzieci i zapewnienia im odpowiedniej dawki ruchu fizycznego - [...] dostarczali nam takich sportowych rozrywek jak krokiet, jazda na rowerze, pływanie, wędrówki piesze $w$ miesiacach letnich oraz tenis podczas wakacji, a w ziemie tyżwy, saneczki i lekcje tańca ${ }^{29}$.

Zima na równi z latem miała na wsi mnóstwo swoistego uroku ${ }^{30}$, jak pisał jeden z pamiętnikarzy, bo dostarczała okazji do zupełnie innych, lecz równie atrakcyjnych zabaw, co inne pory roku. Można było ślizgać się na zamarzniętych stawach i jeziorach czy urządzanych w ogrodach ślizgawkach, saneczkować, brać udział w kuligach, bawić się w śnieżki, lepić bałwany, budować śniegowe fortece. Należało jednak uważać, by przy kilkunastostopniowym lub większym mrozie nie odmrozić sobie nosa, policzków czy uszu lub by nie narazić się na pęknięcie lodu na zbiorniku wodnym i skąpanie w lodowatej wodzie, co przytrafiało się stosunkowo często. Późną jesienią, zimą i wczesną wiosną stawy i jeziora stawały się szczególnie niebezpieczne, kiedy cienka warstwa lodu mogła załamać się pod próbującymi jej wytrzymałości dziećmi ${ }^{31}$. W zimie też, szczególnie w okresie świąt i karnawału odwiedzano rodzinę, sąsiadów i przyjaciół, więc okazji do zabaw, gier towarzyskich i tańców było sporo ${ }^{32}$.

Nie bez znaczenia była też pora zabawy. W dzień, kiedy był jasno, można było biegać, hałasować, wymyślać najróżniejsze gry i zajęcia w każdej niemal części domu czy obejścia. Lecz kiedy o szarej godzinie zapadał mrok i jedynie słabe światło lampy, ognia z kominka, czy świecy oświetlało wnętrza, zabawy nabierały innego, tajemniczego i nie-

27 Ibidem, s. 32; J. z Puttkamerów-Żółtowska, op. cit., s. 53; A. Rostworowski, op. cit., s. 25.

${ }_{28}$ W. Lednicki, op. cit., s. 499, 501; Z. z Rodowiczów-Iwanicka, op. cit., s. 64-65; A. Rostworowski, op. cit., s. 25; A. Wierzbicki, Żywy Lewiatan. Wspomnienia, wstęp i oprac. P. Wierzbicki, Warszawa 2001, s. 52.

${ }^{29}$ Z. z Rodowiczów Iwanicka, op. cit., s. 64; I. J. Paderewski, op. cit., s. 29; J. z Puttkamerów-Żółtowska, op. cit., s. 72.

${ }^{30}$ M. Łążyński, Sto lat bez mała. Wspomnienia lekarza z lat 1869-1956, Warszawa 1961, s. 14.

31 W. J. Grabski, op. cit., s. 89.

${ }^{32}$ C. Czarnowski, op. cit., s. 8; A. Kownacki, op. cit., s. 17; S. Włoszczewski, op. cit., s. 20; K. A. Jaworski, op. cit., s. 21; W. Lednicki, op. cit., s. 36; A. Jaroszewicz, op. cit., s. 23-24; Z. z Rodowiczów-Iwanicka, op. cit., s. 55, 65; J. z Puttkamerów-Żółtowska, op. cit., s. 60; A. Wierzbicki, op. cit., s. 51; W. J. Grabski, op. cit., s. 89. 
co groźnego charakteru. Znajome sprzęty czy miejsca stawały się niemal magiczne, pomieszczenia wypełniały się cieniami, które pełzały po ścianach i suficie i które można było wykorzystać do zabawy. Dla odważnych należało wtedy szukanie się w ciemnych kątach salonu czy pokoju dziecinnego, gdyż do dalszych pomieszczeń zwykle nie odważano się oddalać, z obawy, że bajki o strachach opowiadane przez nianie czy mamy mogą okazać się rzeczywistością ${ }^{33}$.Władysław Matlakowski pisał: Moja piastunka Jagusia, a potem Antonina miała dar do opowiadania. W nocy za to obawiałem się okropnie, nie wyszedłem sam na dwór, nie spałem sam nigdy, a za najmniejszym skrzypnięciem, stuknięciem małom ze skóry nie wyskoczyt! ${ }^{34}$. Jednak nie wszystkie dzieci bały się ciemności. Niektóre chętnie bawiły się, kiedy cały dwór zapadał w sen. Stanisław A. Korwin wspominał jak nocą, z rodzeństwem urządzali taniec karaluchów - zwabiali karaluchy kostką cukru, a potem odstraszali światłem świecy - karaluchy to biegły do cukru, to uciekały przed światłem - zabawa trwała tak długo, aż starczało świecy ${ }^{35}$.

Długie jesienne i zimowe wieczory były też okazją do słuchania opowieści, bajek, a szczególnie historii o bohaterach narodowych czy rodzinnych, powstańcach, walkach narodowowyzwoleńczych, które potem stawały się inspiracją do zabaw w wojny i bitwy. Najczęściej opowieści te snuli dziadkowie, ojcowie, ale i matki, babcie, nianie, nauczyciele i nauczycielki domowe lub goście dworu. Bywało, że towarzyszyły im śpiewy pieśni patriotycznych, religijnych a nawet ludowych. Dzieci zwykle lubiły te wieczory i niecierpliwie czekały na nowe historie, które stawały się często pierwszymi lekcjami historii ojczystej. Nie brakowało jednak także opowieści o diabłach, upiorach, strzygach, zaklętych księżniczkach i innych złych duchach czy czarach ${ }^{36}$. Przy blasku świec, lampy czy kominka czytywano też powieści, prasę, bajki, grywano w gry towarzyskie ${ }^{37}$.

33 Zob. ibidem, s. 22-23, Kochany dom tymoszowiecki w nocy nabierat nieokreślonej grozy. Bałam się go od dzieciństwa i nie było właściwie ani jednego pokoju, gdzie bym się nie obawiała spać sama - pisała Zofia Szymanowska, opowiadając także o tajemniczych dziwiękach, przesuwaniu mebli i innych niewyjaśnionych zdarzeniach w Tymoszówce, w: Z. Szymanowska, op. cit., s. 18-21.

${ }_{34}$ W. Matlakowski, Wspomnienia z życia przeszłego i teraźniejszego (1850-1895). Z rękopisu do druku przygotował, przedmową i komentarzem opatrzył J. Kapuścik, Wrocław-Warszawa-Kraków 1991, s. 33.

35 S. A. Korwin, Na przełomie dwóch epok, Warszawa 1966, s. 37-38.

36 Piastunka Henryka Wiercińskiego, Walkowa [...] była nieprzebranq skarbnica bajek - o młynarzach, zbójcach, zaklętych księżniczkach i tysięcznych cudownościach. Gdyśmy słuchajac objawiali niedowierzanie $w$ te nadzwyczajne cudowności, uspokajała naszq nieufność sakramentalnym jakby orzeczeniem: Już tak Pan Bóg dal, w: H. Wierciński, Pamiętniki, Lublin 1973, s. 68; patrz też: Z. Szymanowska, op. cit., s. 37; A. Wierzbicki, op. cit., s. 36-37, 64-65, W. Matlakowski, op. cit., s. 33; Wspomnienia naszej matki, op. cit., s. 145-146; K. Iłłakowiczówna, op. cit., s. 32-33, 166-167; K. Pruszyński, Wspomnienia, reportaże, artykuły, t. I, Warszawa 2000, s. 52-53; W. Lednicki, op. cit., s. 520; J. D. Muśnicki, op. cit., s. 14; J. Iwaszkiewicz, op. cit., s. 20 , 28; M. Zaruski, Wśród wichrów i fal, w: H. Stępień, Mariusz Zaruski. Opowieść biograficzna, Warszawa 1997, s. 10; M. K. Dziewanowski, Jedno życie to za mało. Kartki z pamiętnika niepoprawnego optymisty, Toruń 1994, s. 13-14; W. Sieroszewski, op. cit., s. 11-12, 526-527; M. Łążyński, op. cit., s. 11; S. Żeromski, Dzienniki 1882-1886, opracowała J. Kądziela, Warszawa 1953, s. 43; M. Jałowiecki, op. cit., s. 15; J. z Puttkamerów-Żółtowska, op. cit., s. 53; M. Leśkiewicz, Kartki ze starego albumu, Kraków 1975, s. 23-28; W. Wiśniewski, op. cit., s. 27; S. Swianiewicz, Dzieciństwo i młodość, Warszawa 1996, s. 15-17; M. Czapska, Europa w rodzinie. Czas odmieniony, Kraków 2004, s. 199.

${ }^{37}$ Po kolacji graliśmy $w$ warcaby, mlynek, halmę $i$ domino z nauczycielkami, albo przegląaliśmy pisma ilustrowane [...], w: ibidem. 
W zabawach dziecięcych istotne jest także towarzystwo. W rodzinach, w których dzieci było dwoje lub więcej, pierwszymi i często najlepszymi towarzyszami zabaw byli oczywiście bracia i siostry. Najkorzystniejszą sytuacją było, kiedy dzieci nie dzieliła zbyt duża różnica wieku. Starsze dzieci bawiły się z wtedy z nieco młodszymi, wprowadzały je w tajniki swoich gier, pokazywały ulubione miejsca do zabaw, kierowały i organizowały często ich przebiegiem. Bywało jednak i tak, że młodsze o kilka lat rodzeństwo stanowiło niewygodny ciężar, psujący zabawę, którego starsi pragnęli się jak najszybciej pozbyć, nawet kosztem bury od bony czy rodziców ${ }^{38}$.

O towarzystwie do zabawy decydował nie tylko wiek, ale i płeć kompanów. Chłopcy, jak pisała jedna z pamiętnikarek - na ogót nie kochali zabaw z dziewczynkami ${ }^{39}$, szczególnie młodszymi od siebie. Raczej niechętnie więc spędzali czas z panienkami, uważając je za słabsze, mniej mądre i odważne ${ }^{40}$. Kazimierz Andrzej Jaworski, wspominając wspólne zabawy z dziećmi znajomych rodziców pisał, że podczas zabaw w parku dziewczynki [...] przynosity ze sobq drewniane kótka, które toczyły pałeczkami, sznurki do skakania, plotty wianeczki z kwiatów i śpiewaty. Chłopcy [...] woleli się gonić po alejach, bawić w chowanego $i$ wspinać na drzewa ${ }^{41}$. Jak to zwykle jednak bywa, od reguły muszą być wyjątki i pamiętnikarz wspominał koleżankę, która bawiła się z chłopcami, była silna, energiczna i lubiła przewodzić - dokazywała na równi z nami i potrafiła ku zgorszeniu swych towarzyszek wdrapywać się na gałęzie ${ }^{42}$. Bywały też sytuacje, że w majątku czy jego okolicy nie było zbyt dużej liczby dzieci, wtedy chłopcy akceptowali obecność dziewcząt, woląc zabawy wspólne, niż samotne ${ }^{43}$.

Stosunkowo rzadko znajdujemy we wspomnieniach opisy wspólnych zabaw dzieci z rodzicami. Można przypuszczać, że rodzice mieli swoje, dorosłe i poważne sprawy, które nie pozostawiały na wspólne spędzanie z dziećmi wiele czasu ${ }^{44}$. Jeśli już rodzice

\footnotetext{
38 Wacław Jędrzejewicz wspominał: Byłem najmłodszy $w$ rodzinie, z dużq różnicq wieku [...] Nigdy się z nimi (rodzeństwem) nie mogłem bawić. Pędzono mnie jak pętaka, tak, że właściwie byłem bardzo samotny, w: W. Jędrzejewicz, Wspomnienia. Opracował i posłowiem opatrzył J. Cisek, Wrocław-Warszawa-Kraków 1993, s. 7; Józef Dowbor Muśnicki wspominał: Od siódmego roku przebywałem w samotności - starsze rodzeństwo uznawało mnie za berbecia, a rówieśnicy wiejscy byli zajęci już pracq przy gospodarstwie, w: J. D. Muśnicki, op. cit., s. 16; O licznych zabawach z siostrami - zarówno starszymi i młodszymi pisała obszernie Jadwiga Ostromęcka, w: J. Ostromęcka, op. cit., s. 57-67; zob. też: J. W. Grabski, op. cit., s. 16, 36; W. Lednicki, op. cit., s. 520-521; S. Grabski, Pamiętniki. Do druku przygotował i wstępem opatrzył W. Stankiewicz, Warszawa 1989, s. 18.

39 K. Libiszowska-Dobrska, op. cit., s. 38.

${ }^{40}$ W. J. Grabski, op. cit., s. 49.

${ }^{41}$ K. A. Jaworski, op. cit., s. 20-21.

42 Ibidem, s. 21.

${ }^{43}$ K. Libiszowska-Dobrska, op. cit., s. 38; Z. Szymanowska, op. cit., s. 23-24.

${ }^{44}$ Rodzice moi bezsprzecznie byli ludźmi bardzo inteligentnymi i wyksztatconymi, ale dzieci prawie nie wychowywali. Nie mieli na to czasu i pewnie nie dostrzegali tego zagadnienia. Nasz intelekt ksztaltowat się jako wypadkowa wplywów rozmaitych wychowawców $i$ wychowawczyń, nauczycielek $i$ nauczycieli, w: S. A. Korwin, s. 69; Jeszcze widzę, jak pod okiem matki, młodej a jednak poważnej, nas czworo wówczas dzieci bawi się w obszernej sali domu rodzicielskiego w Geranonach - wspominał H. Korwin-Milewski, w: H. Korwin-Milewski, Siedemdziesiat lat wspomnień (1855-1925), wstęp A. Szwarc, P. Wieczorkiewicz, War-
} 
organizowali dzieciom zabawy czy brali w nich udział, to częściej były to matki ${ }^{45}$. Aleksandra Ostroróg-Sadowska, matka czwórki dzieci - trzech synów i córki szczególnie troszczyła się o ich zabawy i rozrywki, odbywane po zajęciach lekcyjnych. Najchętniej organizowała im czas na świeżym powietrzu - latem długie spacery, wyścigi konne, zajęcia gimnastyczne, zimą saneczki, jazda na łyżwach, a także lekcje tańca, kinderbale, teatry amatorskie ${ }^{46}$. Janina z Puttkamerów Żółtowska w swoich wspomnieniach przywoływała obraz matki, która dla zabawienia córki opowiadała jej własne wspomnienia z dzieciństwa - zabawy z rodzeństwem w parku, podróże konne, sypianie na sianie pokrytym dywanami, w walizkach. Jednak opisując ojca, wspominała go jako zjawisko nieuniknione, ale niezrozumiate. Prawie ciagle wyjeżḋat do Wilna, a w domu zajmowat stanowisko nieprzystępne i trochę groźne ${ }^{47}$. Pamiętnikarze zdecydowanie rzadziej wspominają wspólne zabawy z ojcami, a jeśli już o nich piszą, podkreślają wyjątkowość tej sytuacji. Z pewnością spowodowane było to faktem, że mężczyźni rzadziej przebywali w domach, zajęci zarządzaniem majątkami, interesami sprawami gospodarskimi, narodowymi $^{48}$. Władysław Jan Grabski wspominał rzadkie spotkania z ojcem i wspólne z nim zabawy: Tatusia rzadko ogladamy, przyjeżḋa i odjeżdza, a gdy przebywa z nami jest [...] nie taki miękki $i$ wesoty jak mamusia, jest powazny, nawet wtedy, kiedy się z nami bawi. Tylko z nami potrafi się bawić, na przykład gdy mamusia proponuje: pobaraszkuj Włado z Władziem, wolno mi wtedy wspią́ się na tóżko, gdzie tatuś-Włado jeszcze leży, turla mnie po kołdrze i zaśmiewamy się $[\ldots]^{49}$. Zofia Szymanowska z kolei, obszernie opisując w swych wspomnieniach ojca podkreślała, że poświęcał on wiele czasu swoim dzieciom, ucząc je w domu, ale też i bawiąc się wspólnie z nimi. Umiejętnie łączył naukę z zabawą, co powodowało, że dzieci z radością towarzyszyły mu w jego zajęciach. Ukończywszy prace dzienna $w$ gospodarstwie, oddawat się papa z rozkosza studiom i obserwacjom

szawa 1993, s. 14; W. Sieroszewski, op. cit., s. 13; Jordan (J. Wieniawski), Kartki z mego pamiętnika, t. I, Warszawa 1939, s. 7.

45 Krystyna Libiszowska Dobrska podkreślała, że ojciec nie zajmował się wychowaniem dzieci, zaś z matką łączyła je wyjątkowa zażyłość, potrafiła nie tylko organizować im zabawy, ale i wyleczyć rozbite kolano czy naprawić zepsutą zabawkę, w: K. Libiszowska-Dobrska, op. cit., s. 15; We wspomnieniach Jadwigi Ostromęckiej znajdujemy np. informację, że matka bardzo interesowała się zabawami dziewczynek lalkami: Mieszkanie lalek od czasu do czasu odwiedzała kochana matka nasza, interesująca się żywo stosunkami i przeżyciami $w$ domach lalczynych panujacymi, w: J. Ostromęcka, s. 58; Zofia Szymanowska wspominała ulubione, lecz rzadkie chwile, kiedy chorując, mama poświęcała jej dużo czasu, czytając bajeczki, grając w karty i wycinając obrazki, w: Z. Szymanowska, op. cit., s. 42.

${ }^{46}$ Latem odbywaty się wyścigi konne albo wkoło dużego klombu, albo przez park prosto od gorzelni. Była urzqdzona niby to trybuna z sędziami, którzy rozdawali medale $w$ formie monet przedziurawionych złotych, srebrnych czy miedzianych na czerwonych czy niebieskich kokardach. [...] Mała wówczas Janinka koniecznie też brała udział $w$ wyścigach na swoim, przybranym $w$ kolorowe frędzle $i$ dzwonki osiołku [...] przybywała naturalnie ostatnia, ale zawsze to przyjmowano hucznymi oklaskami i śmiechem, w: J. Umiastowska z Ostrorogów, op. cit., s. 79-80.

47 J. z Puttkamerów-Żółtowska, op. cit., s. 10, 68.

${ }^{48} \mathrm{O}$ zaangażowaniu ojców z polskich rodzin ziemiańskich w wychowanie dzieci, także we wspólne zabawy patrz: M. Nawrot-Borowska, Wizerunek ojca $w$ polskich rodzinach ziemiańskich w świetle pamiętników z lat 1850-1914, w: Mężczyzna w rodzinie i społeczeństwie - ewolucja ról w kulturze polskiej i europejskiej, t. I: Od średniowiecza do poczqtku XX wieku, red. K. Kabacińska, K. Ratajczak, Poznań 2010, s. 109-138.

49 W. J. Grabski, op. cit., s. 14. 
w towarzystwie zaciekawionych dzieci, które dreptaty za nim, wstuchane w jego obszerne, dostępnie podane objaśnienia [...] Urzadzano nieraz teatry amatorskie, w których papa brat czynny udziat $i$ byt jednym z lepszych aktorów ${ }^{50}$. Ignacy Jan Paderewski już jako kilkulatek regularnie grywał z ojcem w szachy i była to ich ulubiona wspólna rozrywka ${ }^{51}$.

Obok rodziców, istotną rolę w życiu dzieci odgrywali dziadkowie, którzy często zamieszkiwali z rodziną we dworze, lub rezydowali w nim przez określony czas. Henryk Wierciński, którego dzieciństwo przypadło na połowę wieku XIX wspominał swoją ulubioną towarzyszkę zabaw - babkę. Nie tylko sprawowała ona nadzór nad wnukami i opiekowała się nimi, ale organizowała zabawy, obdarzała pieszczotami, uczyła wierszyków i opowiadała wspaniałe bajki ${ }^{52}$. Zofia Szymanowska, wspominając swoje dzieciństwo w poczatku XX wieku, pisała: Wieczorami zbierała babunia w swoim pokoju wszystkie dzieci i czytała im głośno. Zasiadaliśmy wówczas przy stole w babuni pokoju, z farbami, dekalkomaniq lub jakaśs brudnawa robótka i słuchaliśmy w milczeniu opowieści o rzewnych losach Róży na Tannenburgu i wzruszały nas do łez szlachetne czyny Ostatniego Mohikanina ${ }^{53}$. Mieczysław Jałowiecki opisywał zajęcia z dziadkiem - wspólne pływanie czółnem, nocne wyprawy na raki, polowania o świcie - Dziadek nauczyt mnie kochać przyrodę. Otworzyt mi oczy na ten zaczarowany, niedostepny dla obcych świat pachnqcy świeża trawa skoszonych łak, wilgociq lasów i dymami ognisk na kartofliskach ${ }^{54}$.

W rodzinach ziemiańskich popularne było, że do opieki nad małymi dziećmi zatrudniano piastunki i bony, zaś dla dzieci w wieku szkolnym guwernantki i guwernerów. To ich zadaniem, obok nauki, było sprawować pieczę nad dziećmi, także podczas zabaw. Jednak mało kto z najemnych opiekunek czy opiekunów brał czynny udział w dziecięcych swawolach - zwykle ich rola ograniczała się do wyznaczenia pory zabawy czy spaceru i czuwania nad bezpieczeństwem dziecii ${ }^{55}$, co nie było zadaniem łatwym w przypadku ruchliwej i pełnej pomysłów dzieciarni. Niejednokrotnie zdarzało się, że dzieci sprytnie uciekały spod opieki opiekunek czy opiekunów ${ }^{56}$. Poza godzinami lekcji dzieci

${ }^{50}$ Z. Szymanowska, op. cit., s. 28, 29.

51 I. J. Paderewski, op. cit., s. 38; wspólną z ojcem grę w szachy, praktykowaną już od 7 roku życia, wspominał I. Mościcki. Prezydent RP. Autobiografia, Słowo wstępne prezydent RP L. Wałęsa, wstęp, przypisy oraz wybór wywiadów i deklaracji publicznych M. M. Drozdowski, Warszawa 1993, s. 18.

${ }^{52}$ H. Wierciński, op. cit., s. 33; zob. też: Z. Szymanowska, op. cit., s. 37; W. J. Grabski, op. cit., s. 62.

53 Z. Szymanowska, op. cit., s. 36.

${ }^{54}$ M. Jełowiecki, op. cit., s. 46; wspólne zabawy z dziadkiem wspominała także: J. z Puttkamerów-Żółtowska, op cit., s. 53 .

55 A. Rostworowski, op. cit., s. 15.

${ }^{56}$ Helena Ceysinger wspominała spacery z bona, podczas których nie mogła biegać swobodnie po łąkach czy polach, by nie zniszczyć bucików. Kiedy tylko bona odwracała wzrok, dziewczynka uciekała w wysokie trawy, w: H. Ceysinger, op. cit., s. 34-35; Zofia Szymanowska wspominała swoją piastunkę, Babę Hannę, która była prostą chłopką, uwielbianą przez wszystkie dzieci w rodzinie. Siadała z nimi na trawniku przed oficyną i opowiadała skazki (bajki) [...] i zaczynało się o siwym koniu i odważnym kozaku, madrym chłopie i diable rogatym $i$ w końcu najmilsza bajka o lakomej kozie, w: Z. Szymanowska, s. 54; O zabawach pod opieką bon i guwernantek wspominali: S. Włoszczewski, op. cit., s. 12; K. A. Jaworski, op. cit., s. 21; K. Iłła- 
mogły niczym nieskrępowane biegać po catym parku, łowić ryby, chodzić do stajni, z daleka tylko i teoretycznie dogladane przez pedagogium, które miało swoje sprawy i zainteresowania - pisał Andrzej Rostworowski. Zofia Szymanowska z kolei miała bardzo zaangażowana w opiekę nad dziećmi guwernantkę, pannę Clemencie, która opiekowała się nami z nieustępliwa obowiazkowościa. Przy niej bawiłyśmy się, z niq chodzityśmy na spacer [...] Miała dla nas mnóstwo historyjek, opowiadań, nowych zabaw i robótek ${ }^{57}$. Henryk Wierciński wspominał swojego ulubionego guwernera, z którym lekcje odbywaliśmy w najlepszej zgodzie, a potem bawiliśmy się razem czy to jeżdzac konno, czy do lasu na jagody, czy w pole na żniwa ${ }^{58}$.

Wiejskie dwory odwiedzane były przez różnych gości, z których niektórzy bawili w nich nawet po kilka miesięcy lub dłużej. Przez dom przewijała się więc plejada cioć, wujków, kuzynów i innych dalszych lub bliższych krewnych czy przyjaciół domu. Dla dzieci była to okazja do zabaw w nowymi towarzyszami. Władysław Jan Grabski wspominał swojego stryja Stanisława, z którym chłopcy uwielbiali się bawić. Wuj miał pomysły na zabawy na każdą pogodę i chętnie spędzał czas z bratankami, bawiąc się równie dobrze jak oni. Kiedyś nawet samodzielnie przystrzygł żywopłot przed domem, żeby chłopcy mogli przeskakiwać go, ćwicząc skoki wzwyż ${ }^{59}$. We wspomnieniach Piotra Mańkowskiego odnajdujemy informacje o ciotce, stryjecznej siostrze babki autora wspomnień, która bardzo angażowała się w zabawy z dziećmi. Potrafiła łączyć zabawy z nauką, rymowankami uczyła krain geograficznych, zaś uczone przez nią wierszyki i piosenki długo zostawały w pamięci. Do ulubionych zajęć dzieci było wspólne z ciotką sporządzenie odlewów palców ze stearyny - zabawa, choć nieco bolesna, bo gorący wosk parzył palce, dawała wiele radości i na długo zajmowała starsze rodzeństwo pamiętnikarza ${ }^{60}$. We wspomnieniach Marii Czapskiej znajdujemy opis zabaw z ulubionym księdzem Zelbo. Kochat dzieci, młodsze rodzeństwo nosił jeszcze na barana, robił z nami kubek, czyli koziołek przez głowę, razem z nami żłobit kanaty, torujac ujście kałużom drogowym [...] Z zapatem brat udziat w naszych zabawach, Podkasawszy rewerende kopat pitke, grat $w$ tenisa, $w$ zimie lub $w$ dzdżyste, niedzielne popoludnia zasiadat $z$ nami przy miednicy z ciepła woda, w której odklejały się znaczki pocztowe ${ }^{61}$.

Po domownikach, czy rezydujących na dłuższy lub krótszy okres we dworze gościach, należy wspomnieć także o ludziach pracujących we dworze, służbie - kucharkach, stangretach, stajennych, fornalach, pastuchach, oborowych, ogrodnikach i innych, którzy często stawali się towarzyszami i inicjatorami zabaw dziecięcych. Najmłodsi chęt-

kowiczówna, Niewczesne wynurzenia, Warszawa 1958, s. 23; J. Ostromęcka, op. cit., s. 166, 174; M. Czapska, op. cit., s. 199; S. Kieniewicz, op. cit., s. 67; W. Lednicki, op. cit., s. 34, 36.

57 Z. Szymanowska, op. cit., s. 54.

${ }^{58}$ H. Wierciński, op. cit., s. 68.

59 W. J. Grabski, op. cit., s. 62; Obszerne wzmianki na temat wspólnych zabaw z wujem, bratem ojca, który „był wesoly, szalał z nami, dziećmi i bawił się w różnych miejscach” zawarła w swych wspomnieniach A. Gayer, w: A. Gayer, op. cit., s. 10.

${ }^{60}$ P. Mańkowski - biskup kamieniecki, arcybiskup tytularny egejski, Pamiętniki, Warszawa 2002, s. 9.

${ }^{61}$ M. Czapska, op. cit., s. 180. 
nie spędzali czas na terenie dworskiego obejścia, poszukując ciekawych zajęć i pomysłów na zabawy (często bez zgody bon czy rodziców). Bywało, że między służbą dworską, a dziećmi państwa rodziły się przyjaźnie, które po latach były z rozrzewnieniem wspominane. Wykonywane przez pracowników dworskich codzienne obowiązki były dla dzieci interesujące i ciekawe, imponowali im oni zwykle swoimi umiejętnościami, zaś przyzwolenie na wzięcie udziału w jakiejś pracy było dla najmłodszych nie lada atrakcja, a przy okazji i szkołą życia. Dzieci (choć zwykle te nieco starsze, w wieku szkolnym), skakały więc przez rowy z pastuszkami, urządzały sobie wraz z nimi zjeżdżalnie ze stogów siana, piekły w ognisku ziemniaki, plotły postronki i baciki ze stajennymi, czesały koniom grzywy i ogony, strugały fujarki z kory wierzbowej, próbowały pracować narzędziami - heblem, młotem, kowadłem, motyką, uczac się $w$ zabawie umiejętności, o których miejscy chtopcy nie maja pojęcia, a w podręcznikach szkolnych brak o nich choćby wzmianki ${ }^{62}$.

Niejednokrotnie dzieci ze dworu przyjaźniły się i spędzały czas z dziećmi służby pracującej we dworze, a także $\mathbf{z}$ okolicznych wiosek ${ }^{63}$. Bywało, że zapraszano dzieci wiejskie do parku dworskiego, by mali ziemianie mieli towarzystwo do zabaw, uczyli się szacunku dla innych oraz nabywali kompetencji społecznych. Tak było w przypadku Władysława Jana Grabskiego, który wraz z bratem, zachęcany przez rodziców spotykał się z dziećmi ze wsi, bawiąc się z nimi w zabawy, które zwykle były zakazywane przez bony, jak np. wchodzenie na drzewa, skoki przez rowy, szalone gonitwy po ogrodzie czy poznawanie zwyczajów płazów i owadów ${ }^{64}$. Stanisław A. Korwin, z zaprzyjaźnionymi wiejskim chłopcami wytyczał ścieżki przez torfowe mokradła, zbierał wszelkie gady, które potem hodował w skrzyniach i słojach, budował na drzewach gniazda, żeby zapoznać się z życiem ptaków ${ }^{65}$. Józef Dowbor Muśnicki pisał o przykrych konsekwencjach wspólnych zabaw z dziećmi ze wsi: Na wsi, gdzie przebywałem do lat 10, chwile wolne od nauki [...] spędzałem $w$ towarzystwie rówieśników - wiejskich chtopców. Przeżycia owych chwil ograniczaty się do biegania po wertepach w pogoni za ptakami, wiewiórkami itp. Niejednokrotnie obrywatem cęi, gdy to urwisowanie się przekraczało ściśle określony czas lub wychodziło poza granice dopuszczalne, nawet jak na wiejska swobodę. Sprawiedliwość wymaga zadokumentowania, że gdy paniczowi sypano skórę we dworze, wtórowały temu wrzaski rówieśników ze wsi, którym pasami ojcowie także wszczepiali zasady życiowej madrości ${ }^{66}$. Nie wszyscy jednak członkowie rodzin ziemiańskich byli zwolennikami tego typu kontaktów. Niektórzy z rodziców czy dziadków zakazywali wręcz zabaw z dziećmi chłopskimi, obawiając się negatywnego wpływu na moralność

\footnotetext{
${ }^{62}$ W. J. Grabski, op. cit., s 109, 43-44, 55, 104, 110; Kazimierz Andrzej Jaworski zaprzyjaźnił się ze stangretem, który oprowadzał go po stajni, opowiadał o koniach, pozwalał bawić się w wozowni, gdzie chłopiec urządzał sobie wymyślone podróże powózkami, bryczkami, furmankami, w: K. A. Jaworski, op. cit., s. 11; zob. też: A. Gayer, op. cit., s. 12; P. Mańkowski, op. cit., s. 9; C. Czarnowski, op. cit., s. 38; A. Kownacki, op. cit., s. 26; Z. Szymanowska, op. cit., s. 30-32.

${ }^{63}$ W. Sieroszewski, op. cit., s. 38; W. Jędrzejewicz, op. cit., s. 7; W. Wiśniewski, op. cit., s. 26.

${ }^{64}$ W. J. Grabski, op. cit., s. 33, 48.

65 S. A. Korwin, op. cit., s. 21.

${ }^{66}$ J. D. Muśnicki, op. cit., s. 13.
} 
i obyczaje maluchów, zaś wszelka serdeczność i poufałość między dworem a wsią, nawet na poziomie najmłodszych była niedopuszczalna. Edward Ligocki wspominał, że wyraźnie oddalano go od dzieci wiejskich - postępowano tak wyłącznie z dbałości o czystość języka, pisał, podkreślając, że w mowie jego nie było ukrainizmów, rusycyzmów i innych naleciałości lokalnej gwary ${ }^{67}$. Podobnie było w przypadku Kazimierza Andrzeja Jaworskiego, który pisał: Te dzieci wiejskie, umorusane $i$ bose, z którymi to nie wolno było mi się bawić, żebym nie nauczyt się brzydkich wyrazów, a które pociagaty brzdaca swa innościa, że wciqż do nich garna $t^{68}$. Warto przytoczyć także słowa Jana Skotnickiego, który podkreślał znaczenie zabaw dzieci ziemiańskich z wiejskimi: Bym nie wyrósł na sob$k a$, zwoływano ze wsi na zabawy ze mnq dzieci niektórych gospodarzy. Byli to moi pierwsi niezapomniani towarzysze. Toteż śmieszna wydaje mi się obawa, często jeszcze spotykana u rodziców ze sfery inteligencji, przed obcowaniem ich dzieci z dziećmi wiejskimi. Zapewniam, że tak zwane niestosowności, nieprzyzwoitości i zgorszenia dosięgly mnie dopiero przez dzieci ,dobrze wychowane” w mieście ${ }^{69}$.

Nie wszystkie dzieci miały towarzystwo do zabawy - należały do nich najczęściej te, które nie miały rodzeństwa, a kontakty z dziećmi z otoczenia dworu były im zabronione lub różnica wieku między dziećmi w rodzinie była tak duża, że starsze odrzucały młodsze, pozostawiając je samym sobie. Jeden z pamiętnikarzy z żalem wspominał brak towarzystwa do zabawy, który przyczynił się do tego, że chłopca uważano za zbyt poważnego jak na swój wiek. [...] nie miałem żadnych towarzyszy. Bez nich żadnych zabaw chtopięcych nie mogłem uprawiać [...] zawsze wśród starszych od siebie [...] daleki od rówieśników $i$ zabaw z nimi, byłem nad lata poważny $i$ do innego życia nawet nie tęskni$\iota^{70} \mathrm{~m}^{70}$. Co więc ciekawe, dzieci przywykały do samotności i znajdowały sobie inne zajęcia, rekompensujące im swawole $\mathrm{z}$ innymi. Wacław Jędrzejewicz, odrzucany z racji młodszego wieku przez starsze rodzeństwo, najbardziej lubił bawić się sam i jak pisał, zawsze na trenie dworu znajdował sobie zatrudnienie, które go zainteresowało ${ }^{71}$. Samotne spędzanie czasu wspominała także inna z pamiętnikarek - Kiedy byłam skazana wytacznie na swoje towarzystwo, nauczyłam się sama bawić, a miałam tak wiele zainteresowań, że nie czułam się wcale pokrzywdzona przez los. Połykałam ksiażki i uprawiałam najrozmaitsze hobby, które sq chorobq wieku dziecięcego, a odżywają w starszym wieku sq znakomitym antidotum przeciwko samotności i starości $i^{72}$.

We dworach ziemiańskich istotne miejsce zajmowały także zwierzęta, szczególnie psy. Nie tylko strzegły domu, towarzyszyły panom podczas polowań i domownikom podczas spacerów, ale były także były ulubieńcami najmłodszych, ich opiekunami, kom-

\footnotetext{
${ }^{67}$ E. Ligocki, op. cit., s. 16.

${ }^{68}$ K. A. Jaworski, op. cit., s. 11.

69 J. Skotnicki, Przy sztalugach i przy biurku. Wspomnienia, Warszawa 1957, s. 13.

${ }^{70}$ I. Radliński, Mój żywot, Łuck 1938, s. 14.

71 W. Jędrzejewicz, op. cit., s. 7.

${ }^{72}$ K. Libiszowska-Dobrska, op. cit., s. 38.
} 
panami zabaw i wędrówek. Często rekompensowały brak towarzystwa rówieśników ${ }^{73}$. Kazimierz Andrzej Jaworski opisywał swoje zabawy z psami: Te psy z wygladu $i$ warczenia groźne, a w istocie takie łagodne, pozwalały tarmosić sobie kudty, ciagnać się ogon i służyć za wierzchowca. Zaprzyjaźnitem się z nimi, a wieczorem ich szczekanie kotysało mnie do $s n u^{74}$. Bywało, że psy ratowały dzieci z różnych opresji, głośnym szczekaniem donosząc opiekunom, gdzie znajdują się mali podróżnicy, którym zdarzyło się zbyt oddalić od domu, przepędzały dzikie zwierzęta podczas wycieczek do lasu. Władysław Jan Grabski wspominał swojego ulubieńca, psa Chamka, który uratował jego i brata przed napaścią byka uciekającego z pastwiska, który pędził prosto w kierunku bawiących się nad rowem chłopców ${ }^{75}$. Zdarzało się, że we dworze były także sarenki, koziołki, świnki morskie, myszki, ptaki (żurawie, bociany, kruki, kanarki, synogarlice), a nawet wilki i niedźwiadki, które oswojone, stawały się towarzyszami zabaw ${ }^{76}$.

Często wspominanymi towarzyszami najmłodszych i starszych dzieci były konie. Kiedy dzieci, szczególnie zaś chłopcy, kończyły 6-7 rok życia, nadchodził czas, kiedy zwykle uczono ich jazdy konnej ${ }^{77}$. Choć była to umiejętność, którą każdy młody ziemianin powinien posiąść w charakteryzowanym okresie, dla dzieci stanowiła często przyjemność i traktowana była na równi z zabawą. Bywało, że na początek nauki jazdy rodzice kupowali kuca, który zwykle szybko stawał się ulubieńcem dzieciarni. Jazda na koniu przysługiwała starszym dzieciom, zaś kilkunastolatkowie zwykle mogli sami jeździć konno po okolicy ${ }^{78}$.

Podobnie było z nauką myślistwa, do której chłopcy zaprawiani byli od najmłodszych lat ${ }^{79}$. Początkowo traktowali przygotowanie do tej sztuki jak zabawę, wyrywali pióra ustrzelonym przez myśliwych kaczkom czy bażantom, bawili się lisimi i zajęczymi

73 C. Czarnowski, op. cit., s. 24; A. Kownacki, op. cit., s. 20; E. Ligocki, op. cit., s. 15; K. Błeszyński, O mnie i nie o mnie, Łódź 1963, s. 55-58; W. Lednicki, op. cit., s. 35; W. Sieroszewski, op. cit., s. 10; L. Kaltenbergh, Ułamki stluczonego lustra. Dzieciństwo na kresach. Tamten Lwów, Warszawa 1991, s. 12; Z. Szymanowska, op. cit., s. 97-101.

${ }^{74}$ K. A. Jaworski, op. cit., s. 11.

75 W. J. Grabski, op. cit., s. 28-29.

${ }^{76}$ Ibidem, s. 174; M. Wańkowicz, op. cit., s. 70; W. Wiśniewski, op. cit., s. 29; E. Janiszewski, op. cit., s. 23; H. A. Gayer, op. cit., s. 10.

77 S. Grabski, op. cit., s. 21; I. J. Paderewski, op. cit., s. 29-30; H. Korwin-Milewski, op. cit., s. 31-32; S. Włoszczewski, op. cit., s. 11, 42; Kardynał A. Kakowski, Arcybiskup Metropolita Warszawski, Z niewoli do niepodległości. Pamiętniki, słowo wstępne Ks. Kardynał J. Glemp, red. i oprac. T. Krawczak, Świętek, Kraków 2000, s. 18; Wspomnienia naszej matki, s. 145; W. Lednicki, op. cit., s. 499-500; J. D. Muśnicki, op. cit., s. 17; L. Kaltenbergh, op. cit., s. 13; M. Leśkiewicz, op. cit., s. 54; J. Umiastowska z Ostrorogów, op. cit., s. 80; K. Libiszowska-Dobrska, op. cit., s. 23; Z. Szymanowska, op. cit., s. 49-50.

${ }^{78}$ Melchior Wańkowicz barwnie pisał o przejażdżkach z bratem: Jechało się białymi sapowatymi drogami, jechało się giętkimi ścieżkami uginajacymi się po torfiastych łakach, na przełaj, wrzosowiskami, czarnymi ostępami leśnej próchnicy, o której nie dochodzi słońce, przedzierają się przez gąszcz leśny, zdejmując raz po raz z twarzy pajęczynę [...] Kiedy wydostawaliśmy się na pole, na łaki rozkrzyczane przez derkacze, ogarniat nas potężny zapach kwitnacych koszonych łak [...] szalony galop nióst nas ku domowi przez wywrotne mostki, zaradne dziury, oślizgłe zbocza ścieżek [...], w: M. Wańkowicz, op. cit., s. 96-98.

79 Polowanie było tak ogólnie przyjętym zwyczajem, że młody człowiek nieumiejacy strzelać, nie obyty z obyczajami myśliwskimi robił wrażenie ,niedokończonego” towarzysko - pisał Wacław Lednicki, w: W. Lednicki, op. cit., s. 518; M. Jełowiecki, op. cit., s. 46. 
ogonami, kolekcjonowali łuski po nabojach. Nieco starsi chłopcy otrzymywali od ojca broń i pozwalano im zabijać szkodniki, np. wydry, jastrzębie, czaple, strzelać do kaczek i innych ptaków ${ }^{80}$. W czasie, kiedy chłopcy zaczynali polować, otwierały się przed nimi nowe przestrzenie okolicznych pól, lasów, łąk czy mokradeł, zaś każda wyprawa na polowanie była niezwykłą przygodą ${ }^{81}$.

Bogactwo wspomnień poświęconych zabawom w okresie dzieciństwa wyraźnie wskazuje, że niektóre z zabaw dziecinnych były niebezpieczne dla zdrowia, a nawet życia ich uczestników. Wyobraźnia kilkulatków nie zawsze była w stanie przewidzieć, jakie mogą być konsekwencje pewnych działań, które wydawały się zabawne. Dlatego też w pamiętnikach znajdujemy sporo opowiadań o przygodach niesfornych urwisów, które mocno wryły się w pamięć. Szczególnie barwnie swoje dziecinne przygody podczas zabaw i towarzyszące im wypadki opisywał Władysław Jan Grabski. Raz, bawiąc się ze starszym bratem Waciem w wojnę rosyjsko-japońską, Jan, grający Moskala, wszedł na komodę z zawiązaną na szyi wstążką, której drugi koniec trzymał stojący na podłodze Wacek-Japończyk. Zabawa polegała na wzajemnym przeciaganiu się - Jan miał utrzymać się na komodzie, z której - z całą siłą ciągnąc za wstążkę - próbował go ściagnąć brat. Niestety, wstążka tak mocno zacisnęła się na szyi Janka, że stracił oddech, zsiniał i dopiero krzyki ściągnęły matkę, która w szczęśliwie w odpowiednim momencie zakończyła zabawę. Innym razem chłopcy, zainspirowani lekturą Krzyżaków Henryka Sienkiewicza zorganizowali pojedynek, w którym bronią były kawałki szkła, a który trwał tak długo, aż Władzio otrzymał cios rozcinający mu poważnie policzek. Blizna po tej zabawie pozostała pamiętnikarzowi do końca życia. Podobna sytuacja miała miejsce, kiedy pamiętnikarz, skacząc po deskach w narzędziowni, nadział się prawą stopą na gwóźdź, kalecząc się boleśnie. W czasach, kiedy nie było jeszcze szczepionki przeciwtężcowej była to sytuacja niebezpieczna. Kolejną przygodą, w której Wacio Grabski omal nie stracił życia, był popis pływania na łódce przed gośćmi rodziców. Wcześniej chłopcy często bawili się, pływając łodziami po stawach, tym razem jednak nieszczęśliwe manewrując na zbyt głęboką wodę, Wacio wypadł za burtę. Chłopiec nie umiał pływać, towarzystwo także, na szczęście w ostatnim niemal momencie przybiegł zaalarmowany krzykami pastuch, który uratował panicza. Od tego dnia chłopcy mieli zakaz zabaw nad stawem, zaś następnego lata zatrudniono nauczyciela do nauki pływania ${ }^{82}$.

Siostra Tomasza Zana, Helena wspominała swojego brata, który mając osiem lat najbardziej lubił bawić się z dala od domu, w rowach i wykrotach. Raz wpadł do głębokiego dołu, z którego nie mógł samodzielnie wyjść, i tylko przypadek sprawił, że go odna-

\footnotetext{
${ }^{80}$ Choć Melchior Wańkowicz wspominał, że pierwszą wiewiórkę zastrzelił, kiedy miał zaledwie 7 lat, zaś jego starszy brat, w wieku lat 10 udawał się z leśnikami na trzydniowe polowania. Sam pamiętnikarz brał udział w swoim pierwszym polowaniu z fuzją, kiedy skończył 8 lat, ustrzeliwszy swojego pierwszego w życiu zająca, w: M. Wańkowicz, op. cit., s. 32, 110-111; Tomasz Zan miał zaledwie 6 lat, kiedy wraz z ojcem pierwszy raz uczestniczył w polowaniu, lecz pierwszą broń - wiatrówkę, z której strzelał z upodobaniem do wróbli otrzymał dopiero w wieku 11 lat, w: W. Wiśniewski, s. 24; Ignacy Mościcki jako dziewięciolatek ganiał się samemu po polach z dubeltówkq, w: I. Mościcki, op. cit., s. 16; Wspomnienia naszej matki, s. 148.

${ }^{81}$ W. J. Grabski, op. cit., s. 2651-52; W. Wiśniewski, op. cit., s. 25-26.

82 W. J. Grabski, op. cit., s. 18, 48, 55, 50-51.
} 
leziono. Podczas remontu domu spadł z rusztowania i zahaczył udem o wystający gwóźdź, innym razem rozciął sobie policzek drutem kolczastym, po którym pozostała blizna $^{83}$. Andrzej Kownacki podczas zabawy spadł z wysokiego drzewa, co spowodowało oberwanie się nerki. Jak po latach napisał - nic mnie jednak nie zniechęciło do późniejszej takiej zabawy ${ }^{84}$. We wspomnieniach Mariana Kamila Dziewanowskiego znajdujemy historyjkę o tym, jak chłopcy (autor wraz bratem Tuniem) po przyjęciu zakradli się salonu i powypijali resztki win i likierów z kieliszków. Ta mieszanina najprzeróżniejszych alkoholi, okazała się katastrofalną dawką dla młodzieńczych żołądków. W nocy chłopcy mieli konwulsje i wymioty, i musieli pić dużo rycyny, by oczyścić organizm ${ }^{85}$. Wacław Sieroszewski, kiedy otrzymał swój pierwszy biczyk, udał się do okólnika dla źrebiąt i zaczął je straszyć i przepędzać, aż rozjuszone zwierzęta zaczęły chłopca kopać i skakać po nim, aż stracił przytomność. Innym razem, kiedy zainspirował się walkami byków w Hiszpanii, wziąwszy czerwoną płachtę zaczął nią drażnić w oborze buhaja, który straciwszy cierpliwość, wyskoczył przednimi kopytami na korytarz. Chłopiec uciekając, ze strachu potknął się i wpadł głową do cebra pełnego udojonego wcześniej mleka i pewnie by się utopił, gdyby nie jedna z dójek, która go wyciągnęła ${ }^{86}$.

Swawolne zabawy dziecięce miały mniej lub bardziej poważne konsekwencje nie tylko dla zdrowia ich uczestników. Nie trudno się domyśleć, że podczas zabaw dzieciom zdarzało się wyrządzać różnorakie - większe bądź mniejsze - szkody materialne. Podczas radosnych zabaw często łamano gałęzie drzew, deptano grządki, trawniki, klomby, thuczono okna, zastawę stołową, niszczono meble czy inne sprzęty. Ofiarą zabaw padały także ubrania (które darły się podczas wspinania na płoty czy drzewa, brudziły błotem czy żywicą ${ }^{87}$ ) oraz zabawki (niezwykle interesujące było np. ile w lalce jest trocin i czy klocki odbarwią się po kąpieli w wodzie). Wśród zabaw, które z pewnością były bardziej przejawem wrodzonej ciekawości i żywiołowości dzieci, niż chęci uszkodzenia czego-

83 W. Wiśniewski, Pani na Berżenikach. Rozmowy z Helenq z Zanów-Stankiewiczowa, Londyn 1991, s. $26-27$.

${ }^{84}$ A. Kownacki, op. cit., s. 20; Edward Ligocki wspominał historię, kiedy jeden z chłopców próbował skakać z dachu dworu, naśladując Ikara z przypiętymi do ramion skrzydłami i boleśnie się potłukł: E. Ligocki, s. 17; Różnorakie wypadki podczas zabaw z uszkodzeniem ciała wspominał też m. in.: S. Włoszczewski, s. 18; Atak rozjuszonego dzika podczas biegania po lesie opisywał: K. Błeszyński, op. cit., s. 51-52.

${ }^{85}$ M. K. Dziewanowski, op. cit., s. 30-31.

${ }^{86}$ W. Sieroszewski, op. cit., s. 10.

${ }^{87}$ Ponieważ oboje z siostra biegając po polach i lasach stale zdzieraliśmy buty, co parę miesięcy trzeba byto nam sprawiać nowe - pisał I. J. Paderewski. Pamiętnikarz bardzo obszernie opisuje swój wypadek podczas zabawy: Namiętnie lubiłem wspinać się na drzewa w poszukiwaniu owoców. I oto pewnego dnia zdarzyło mi się zawisnać na gałęzi, niszczqc jedyne moje dobre ubranie, a na nowe w naszej rodzinie rzadko kiedy mogliśmy sobie pozwolić. Ubranko, które $w$ dniu tragedii maiłem na sobie, było śliczne, dopiero co przez ojca kupione kosztem dużych wyrzeczeń. Szczególnie ładna było kurteczka. Przywdziawszy ja, natychmiast wdrapatem się na duża, pokryta niespodziewanq ilościq sęków gruszę. Wspinajac się za przepiekna, różowq, apetycznie wygladajaca gruszka, która wisiała na samym wierzchołku owego niebezpiecznego drzewa, zapomniałem o wszystkim. Nagle ześlizgnąem się, a spadajac podartem zupetnie nowq koszule i pięknq kurteczkę, oraz zaczepiłem kotnierzem o jeden z wystajacych sęków. Wisiałem tak, wołajac pomocy. Ów sęk uratowat mnie, ale zniszczył moje nowe ubranie - było w strzępach, a piękna kurteczka na nic. Ojciec nie ukarał jednak Ignacego, jednak na kolejne nowe ubranko chłopiec musiał długo czekać, nosząc skromne i znoszone ciuchy, w: I. J. Paderewski, op. cit., s. 24-25. 
kolwiek, pamiętnikarze wspominają np. rozebranie na części i wykapanie starego, pamiątkowego zegara, który z powodu brudu i kurzu spóźniał się, zbicie świętego obrazu, podziurawienie portretu rodzinnego stanowiącego cel strzelania z łuków, pocięcie na strzępy nowego pledu ${ }^{88}$. Niestety, zabawy takie miewały często swoje mało przyjemne następstwa. Zwykle bowiem za przewinienia, nawet dokonane przypadkiem, podczas zabawy, dzieci były karane. Czesław Czarnowski, wracając do czasów swojego dzieciństwa opisywał sytuację, kiedy to zakradł się do składziku w ogrodzie, do którego nie wolno mu było wchodzić, a w którym suszyły się jabłka, i chcąc dostać się do owoców, stłukł szybę. Karę wymierzył ojciec, silnymi razami na gołe siedzenie wybijając chłopcu z głowy nieposłuszeństwo ${ }^{89}$. Melchior Wańkowicz opisywał dokładnie gradację kar za przewinienia i psikusy, które często były jego udziałem: stanie w kącie, przywiązywanie do nogi od stołu czy fortepianu, klęczenie i leżnie krzyżem na podłodze w pokoju ${ }^{90}$.

Powszechnie wiadomo, fantazja dziecięca nie ma granic, co znajduje swoje wyraźne odzwierciedlenie w bogactwie pomysłów na zabawy i figle. $\mathrm{Na}$ kartach pamiętników spotykamy opisy najróżniejszych zabaw, od tradycyjnych, zajmujących pokolenia, po wymyślne i wyjątkowe. Chłopcy często organizowali zabawy, w których należało wykazać się odwagą, sprytem i siłą fizyczną - najczęściej były to wojny, walki i gonitwy ${ }^{91}$. Wacław Lednicki opisywał zabawy, których inspiracją i źródłem pomysłów były przeczytane przez rodziców lub samodzielnie książki. Bawił się więc z rodzeństwem w Indian, naśladując postaci z opowiadań Coopera i Aimarda, całe dnie spędzając w krzakach i zrostach parku, tropiąc tajemne kryjówki i zasadzki wyimaginowanych czerwonoskórych. Dzieci często odgrywały sceny z ulubionej „Trylogii” Sienkiewicza, dzieląc role zależnie od płci i siły fizycznej. Walczono szablami - kijami, urządzano ucieczki na koniach - długich gałęziach, zaś rolę Tatarów grały rosnące w parku krzewy, krzaki malin, młode drzewka - świerki i sosny. Każde z dzieci chciało ściąć jak najwięcej głów tatarskich, więc młode pędy drzew i słabsze ich okazy zostawały niszczone, wywołując gniew ojca $^{92}$. Również Mariusz Zaruski bawił się z braćmi w Indian, podróże i wojny. Chłopcy pływali, ścigali się konno na oklep po ścierniskach lub urządzali zawody w strzelaniu z łuku. Jednak najciekawszą zabawą było testowanie odwagi - nocą należało udać się na pobliski cmentarz i przynieść krateczkę z polskim orłem, wyjętą z pudełka, za dnia po-

\footnotetext{
${ }^{88}$ Władysław Jan Grabski wspominał sytuację, kiedy w jego trzyletnie wtedy rączki dostały się nożyczki. Zabawą, jak sobie umyślił, było pocięcie na drobniutkie paseczki kolorowego szkockiego pledu i porozrzucanie jego skrawków, udających żmije, w parku. Żmije miały przestraszyć mamusie, która zamiast uciekać, ukarała chłopca klapsami za zniszczenie nowego koca przeznaczonego na wyjazd do kurortu, w: W. J. Grabski, op. cit., s. 19-20, 92, 62; M. Wańkowicz, op. cit., s. 25.

${ }^{89}$ C. Czarnowski, op. cit., s. 15-16.

${ }_{90}$ M. Wańkowicz, op. cit., s. 25, zob. też: L. Krzywicki, Wspomnienia, Warszawa 1957, t. II, s. 48-49; A. Kownacki, op. cit., s. 19.

91 Tomasz Zan zbierał dzieci parobków i organizował oddziały wojskowe, którymi oczywiście sam dowodził. Siostra pamiętnikarza pełniła rolę sanitariuszki, w: W. Wiśniewski, op. cit., s. 26; Zabawę w wojnę - budowanie fortec, wałów obronnych, armat opisywała też: J. Ostromęcka, op. cit., s. 166.

92 W. Lednicki, op. cit., s. 522-523; zabawy w Indian oraz naśladowanie bohaterów „Trylogii” rozlegle opisywała także: Z. Szymanowska, op. cit., s. 24.
} 
łożnego komisyjnie na którymś z grobów ${ }^{93}$. Jeden z pamiętnikarzy opisuje zabawę, która miała na celu wypróbowanie wytrzymałości na ból. W tym celu przywiązano jedną z dziewczynek rozebraną do pasa do drzewa i smagano ją pokrzywami tak długo, aż nie zaczęła krzyczeć. Co ciekawe, dziewczynka nie wydała z siebie głosu, jedynie łzy płynące po policzkach świadczyły o cierpieniu. Próba ta przekonała chłopców, że dziewczęta, mimo powszechnie przyjętej opinii, wcale nie są słabsze i mniej wytrzymałe od chłopców ${ }^{94}$. W innym pamiętniku znajdujemy próbę wysiedzenia nago na mrowisku 5 minut - co istotne próba udała się, a chłopiec jej poddany biegiem popędził do pobliskiej rzeki, zmyć z siebie dziesiątki owadów ${ }^{95}$.

Dzieci często w zabawach naśladowały codzienną rzeczywistość i zachowania ludzi z najbliższego otoczenia. We wspomnieniach Marii Leśkiewiczowej znajdujemy opis jednej z ulubionych letnich zabaw, organizowanych wspólnie z bratem w ogrodzie - zabawę w lekarza. W gorqce dni lata słodki zapach kwiatów mieszat się z zapachem dojrzewajacych owoców; olbrzymie ważki i różnokolorowe motyle przelatywały nad upojona głowa chodziłam po alejkach, pochylajac się nad cudami przyrody [...] siadaliśmy z Bolkiem do ulubionej zabawy. Bolek byt pacjentem, a ja-doktorem. Kładłam na opalone nogi brata liście babki, przysypywałam kwiatami dzikiego bzu, na piersi przyklejałam liść podbiału. Czasami robiłam mała, wprawna ręka nacierania. Bolek byt cierpliwym pacjentem, ale gdy za dużo było taskotania, szczypania i nacierania, zrywała się z ,tóżka”, wierzgat jak źrebak i zrzucat z siebie drogocenne maści $i^{96}$. Krystyna LibiszowskaDobrska wspominała zabawę w kościół: pod starq akacja rosnqca w pobliżu domu odprawialiśmy msze przed ołtarzem zrobionym z gatęzi $i$ kwiatów. Krysia ubrana $w$ kape z tóżka była księdzem i odprawiała nabożeństwo [...] Henryk, jako organista śpiewat cały czas na głos, grajac równocześnie na dziecinnych cymbałkach. Ja petniłam rolę ministranta, dzwoniqc co sił dzwonkiem, którego używat kamerdyner Piotr, aby oznajmić domownikom, że podano do stołu. Hałasowaliśmy tak głośno, że sprowadziło to jedna z nauczycielek, która z wielkim oburzeniem położyła kres naszej zabawie ${ }^{97}$. Kazimierz Andrzej Jaworski lubił zabawy, będące jednocześnie sztuczkami. Utrzymywał w równowadze na nosie pawie pióro, potem kijek, wreszcie nauczył się trzymać na brodzie krzesło, zaś na nosie palący się lejek papierowy. Wyćwiczył też podrzucanie dwóch piłeczek, na przemian chwytanych do reki. Kiedy opanował te sztuki, zaczęła się ulubiona zabawa dziewięcioletniego wtedy pamiętnikarza w cyrk. Zapraszał dzieci z okolicy, sprzedawał „,na niby” bilety, przygotowywał samodzielnie programy występu, ze spisem poszczególnych numerów i nazwisk wykonawców, którymi był on sam. Pokazywał numery na trapezie, popisy żonglerskie, udawał siłacza, klauna. Marzył wtedy, by w przyszłości zostać dyrektorem cyrku. Został poeta, thumaczem i wydawcą ${ }^{98}$.

\footnotetext{
${ }_{93}$ M. Zaruski, op. cit., s. 9-10.

94 W. J. Grabski, op. cit., s. 49.

95 M. Wańkowicz, op. cit., s. 93.

96 M. Leśkiewicz, op. cit., s. 49.

${ }^{97}$ K. Libiszowska-Dobrska, op. cit., s. 39.

${ }^{98}$ K. A. Jaworski, op. cit., s. 26-27.
} 
Zabawy na powietrzu pozwalały najmłodszym na codzienne obcowanie z przyrodą i poznawanie jej tajników. Bronisław Nietyksza, zainteresowany od najmłodszych lat wszystkim, co go otaczało, a szczególnie przyczynami zachodzących w przyrodzie zjawisk, próbował często wiele z nich rozpoznać w tajemnicy przed rodzicami. A że miał ze strony rodziców stosunkowo dużo swobody, szczególnie w organizowaniu zabaw, pewnego letniego poranka postanowił rozwikłać zagadkę horyzontu i dotrzeć do linii, na której niebo styka się ziemią oraz sprawdzić, co znajduje się za nią. Wędrował kilka godzin, aż głodny i zmęczony dotarł do oddalonej o $8 \mathrm{~km}$ wioski. Po powrocie do domu próba rozwikłania zagadki horyzontu skończyła się tęgim laniem od ojca i decyzją, że skoro chłopiec jest tak ciekawy świata i silny fizycznie, może rozpocząć już systematyczną naukę ${ }^{99}$. We wspomnieniach Janiny z Puttkamerów-Żółtowskiej czytamy o jednej z ulubionych zabaw dziewczynki - zbieraniu kwiatów w ogrodzie - skacząc między rabatami i klombami znajdowała najpiękniejsze okazy do wiązanki i potrafiła rozróżnić woń każdego kwiatu ${ }^{100}$.

Nie brakuje także we wspomnieniach opisów zabawnych żartów i psikusów, które rozbawieni najmłodsi wyrządzali innym w różnych sytuacjach. Ofiarami żartów byli głównie dorośli - piastunki, nauczycielki, rodzice, goście dworu, ale i rówieśnicy czy rodzeństwo ${ }^{101}$. Władysław Jan Grabski, podczas nabożeństwa w kościele, nie mogąc znieść zapachu potu wiejskiej baby, obok której posadziła go bona, wyjął agrafkę spinającą spodnie i podłożył kobiecie pod siedzenie. Ofiara z krzykiem uciekła z kościoła, wywołując niezwykłe poruszenie. Innym razem, kiedy we dworze wizytę składał otyły wuj, chłopiec tak przesunął ruchome siedzenie fotela, że wuj zapadł się, zaklinowując się w nim i dopiero z pomoca pięciu osób został uwolniony. Podczas wizyty jednego z gości z Warszawy na spacerze przekonał go, że nasienna koniczyna to herbata, a kiedy ten próbował ją parzyć, naraził się na pośmiewisko mieszkańców dworu ${ }^{102}$. Melchior Wańkowicz wspominał, jak pewnego razu wdrapał się na dach i wrzucił przez komin otwartym okapem polano, które wpadło prosto do garnka z zupa, parząc dotkliwie kucharkę. Innym razem wieczorem, $\mathrm{z}$ dachu ustępu przez otwór zrzucał na korzystających z niego cegły w ataki sposób, by zrobiły jak najwięcej huku i zgasiły święcę - wszyscy uciekali $\mathrm{w}$ popłochu w niepełnej garderobie, przekonani, że w ustępie straszy ${ }^{103}$. Wśród innych żartów, które wspominali pamiętnikarze było np. wrzucanie żab w dekolty pań podczas spacerów czy pikników, przedrzeźnianie dorosłych, chowanie się do szafy i straszenie innych ${ }^{104}$.

${ }_{99}$ B. Nietyksza, Nadzieje, zludzenia, rzeczywistość. Wspomnienia z lat 1912-1945, Warszawa 1985, s. $19-20$.

100 Może dzieci, będac matego wzrostu, sq bliższe ziemi i latwiej chtonq jej zapachy, toteż skaczqc po trawie, między grzędami i klombami i gromadzqc moja wiqzanke, rozróżniałam woń każdego kwiatu, ostrość werbeny, słodycz floksów, piżmowatość goździków, w: J. z Puttkamerów-Żółtowska, s. 40.

${ }^{101}$ A. Kieniewicz, op. cit., s. 45-46; J. D. Muśnicki, op. cit., s. 16; H. Ceysinger, op. cit., s. 22-23; T. i W. Tatarkiewiczowie, op. cit., s. 350 .

102 W. J. Grabski, op. cit., s. 45, 60.

${ }^{103}$ M. Wańkowicz, op. cit., s. 41.

${ }^{104}$ W. J. Grabski, op. cit., s. 105; W. Lednicki, op. cit., s. 34; M. Wańkowicz, op. cit., s. 16. 
Rodzaje zabaw i sposoby spędzania wolnego czasu zmieniały się w zależności od wieku dzieci. Swobodne i beztroskie zabawy, trwające niemal całe dnie kończyły się ok. 7 roku życia, kiedy to znaczną cześć czasu dzieci zajmowała nauka domowa, zaś ok. 10-11 roku życia oddawano dzieci do szkół średnich - gimnazjów lub na pensje żeńskie. Kończyt się więc mój jedyny w życiu beztroski i jakby bajkowy etap życia - pisał o tym okresie Stefan Włoszczewski ${ }^{105}$. Kiedy dzieci wyjeżdżały do szkół, dwór i jego otoczenie stawały się miejscem wypoczynku i swawoli w okresie wakacyjnym. Lato wolne, wakacje na wsi [...] nieskrępowane niczym godziny na wolnym powietrzu! W polu lub w sadzie, przesycone miodnym, zapachem dojrzewajacych zbóż i owoców - pisał Wiktor Ambroziewicz ${ }^{106}$. Dzieci, a w zasadzie już młodzież, przyjeżdżała do domów często z kolegami lub koleżankami szkolnymi, korepetytorami, dodatkowo zjeżdżała się też część rodziny czy znajomych, więc okazji do zabaw i rozrywek było bardzo wiele, a towarzystwa nie brakowało ${ }^{107}$. Stefan Kieniewicz bardzo obszernie opisywał swoje pierwsze wakacje po powrocie z gimnazjum i organizowane wtedy zabawy. Jakże wesoło spędzałem te moje pierwsze, a niestety tak bardzo krótkie, gdyż zaledwie dwa miesiace trwajace wakacje. Otóż w ciagu pierwszych paru tygodni zaznajomiłem się z nowa broniq i ćwiczyłem się $w$ strzelaniu do celu lub też do innych różnych szkodników - jako to jastrzębi, wron, srok i kotów [...] Moimi konikami jeździłem sam do folwarków [...] Godziny popoludniowe spędzałem najczęściej nad rzeka, na tódce, tak zwanej duszehubce, lub téz z wędka w reku, najczęściej łowią ryby z łódki, czy też wlokac za sobq tak zwanq dorożkę na dtugim sznurze, z przymocowanq do niego przynęta [...] Wielkq rozkosza byta też kapiel w Prypeci [...] Dobrałem sobie do towarzystwa dwóch chłopaków w moim mniej więcej wieku - Władka, syna ogrodnika i Kazika, syna ekonoma. Byli to moi satelici i podkomendni. Towarzyszyli mnie wszędzie na wszelkich moich wyprawach - na łódce, rybołówstwie i podczas kapieli ${ }^{108}$.

Wesołych zabaw nie brakowało także w okresie świąt, kiedy dzieci wracały ze szkół do domów. W okresie świątecznym we dworze panował zwykle wielki ruch i bawiono

105 S. Włoszczewski, op. cit., s. 24.

106 W. Ambroziewicz, Moja przygoda pedagogiczna. O szkole polskiej nieco inaczej. Przygotowała do druku T. W. Nowacki, Warszawa 2000, s. 34; Władysław Jan Grabski stwierdzał, że wakacyjne zabawy w okresie nauki szkolnej stawały się już nieco odmienne, dzieci starsze, mądrzejsze, organizowały sobie czas wykorzystując zdobytą wiedzę - np. zamiast skakać „,na galopa” przez żywopłot klombu, organizowaliśmy skoki przez sznurek na wyznaczonq centymetrem wysokość, w: J. W. Grabski, op. cit., s. 141.

107 Letnia porq zjeżḋali do nas goście z bliska i z daleka, a podczas każdorazowych wakacji szkolnych panowała wszechwładnie gwar $i$ wesołość $w$ dworze skierbieszowskim - pisał I. Mościcki, w: I. Mościcki, op. cit., s. 19; patrz też: K. Kraszewski, Kronika domowa. Silva rerum. Wspomnienia i zapiski dzienne z lat 1830-1881, oprac. Z. Sudolski, Warszawa 2000, s. 474-475, 502; E. Ligocki, op. cit., s. 37; A. Iwański (junior), Wspomnienia 1881-1939. Słowo wstępne J. Iwaszkiewicz, oprac. W. Zawadzki, Warszawa 1968, s. 285; S. Włoszczewski, op. cit., s. 42-43; A. Kieniewicz, op. cit., s. 66-67; S. Krzywoszewski, op. cit., s. 13, 22; W. Tomaszewicz, Ze wspomnień lekarza, Warszawa 1965, s. 41; Wspomnienia naszej matki, s. 146; W. Lednicki, op. cit., s. 23; J. Iwaszkiewicz, op. cit., s. 98-99; M. Łążyński, op. cit., s. 38; L. Bochwic, I-Wspomnienia uniwersyteckie. Warszawa 1882-1885. Petersburg 1885-1887. II - Z dawnych wspomnień sadowych, Wilno 1938, s. 25-26; J. z Puttkamerów-Żółtowska, op. cit., s.46; J. Umiastowska z Ostrorogów, op. cit., s. 79; Z. z Rodowiczów Iwanicka, op. cit., s. 78-79.

108 S. Kieniewicz, op. cit., s. 66-67. 
sie niemal bez przerwy, oczywiście w zależności od wieku. [...] małe mikrusy były strzęsione do jednego pokoju, kilkoletniejsze w różne tam „,cztery katy a piec piaty” bawity się w stołowym pokoju (przy czym się wróżyło: erczyk, perczyk, puma guli-wylecieli na Trzy Króli. Panie Janie Kapistranie, czemu nie grasz na organie? Grałem, grałem, zapomniałem, ale teraz przypoemniełem - uno, duo, tres - zaba, baba, zajac, pies!), a młodzież w salonie tańczyła ${ }^{109}$ - pisał Melchior Wańkowicz. Wspominając swawole w okresie świąt Bożego Narodzenia i Nowego Roku opisywał żarty tkj. słanie prześcieradeł na prętach leszczynowych zamiast na ramie z materacem, podczas gdy pod łóżkiem stawiano nieckę z woda, zaszywanie w mankietach rękawów nocnych koszul i wsypywanie w nie mąki, straszenie dziewcząt, wkładanie im do łóżek udających trupy manekinów, przebieranie się w prześcieradła i brzęczenie łańcuchami udając duchy, naśladowanie wycia wilków pod oknami, wsypywanie do nocników ziaren karminu, które barwiły mocz na czerwono, polewanie śpiącego woskiem itp. ${ }^{110}$ Po wyjeździe młodzieży do szkół, dwór zwykle stawał się cichy i spokojny.

Nieodłącznym elementem rozrywki w życiu rodzin ziemiańskich była muzyka w każdym niemal dworze grywano na instrumentach, śpiewano i tańczono. Zimą, najczęściej w okresie karnawału, ale zdarzało się, że i winnych okresach roku organizowano baliki i przyjęcia dla dzieci, zwane też kinderbalami - Dzieci miały swoje tak zwane kinderbale i przyjęcia z okazji imienin. Odbywaty się one po poludniu i trwały nie dtużej, jak do ósmej wieczorem - wspominał Kazimierz Andrzej Jaworski ${ }^{111}$. Helena z Zanów Stankiewiczowa pierwszy raz brała udział w kinderbalu, kiedy miała 5 lat ${ }^{112}$. Na kinderbale często zapraszano gości z sąsiedztwa, zaś najmłodsi mieli okazję pochwalić się swoimi umiejętnościami tanecznymi, znajomością etykiety towarzyskiej, nawiązać znajomości z rówieśnikami ze swojego stanu. Zofia z Rodowiczów Iwanicka wspominała: Rodzice nasi dobrze wiedzieli, ̇̇e nauke trzeba przeplatać rozrywka $i$ wypoczynkiem. Toteż od najmłodszego dzieciństwa uczyli nas tańczyć [...] i często urządzali wieczorki taneczne pomiędzy znajomymi [...] Święta Bożego Narodzenia, zapusty, święta Wielkiejnocy mijały gwarno $i$ wesoło na ciagłych potańcówkach, matka nasza i pani Maria Malikiewiczowa, grajac na fortepianie stanowity stała, niezawodnq orkiestre, a my hasaliśmy z całej duszy podczas beztroskich lat naszego dzieciństwa ${ }^{113}$. Bywały jednak sytuacje, że tańczono także w mniejszym gronie, składającym się z rodziców i dzieci, rezydentów czy gości dworu, zaś salą balową była bawialnia czy nawet korytarz ${ }^{114}$.

\footnotetext{
109 M. Wańkowicz, op. cit., s. 39; Zofia Szymanowska wspomniała: Na Sylwestra [...] tańczyliśmy w przebraniach i robiliśmy wróżby, petni szalonej, beztroskiej zabawy, w: Z. Szymanowska, op. cit., s. 58.

110 M. Wańkowicz, op. cit., s. 38-39, 46.

111 K. A. Jaworski, op. cit., s. 22; W imieniny pamiętnikarza, Andrzeja Wierzbickiego dzieci tradycyjnie lały wosk na wodę i z rzucanych na ścianę cieni odlanych figurek wróżyły, co przyniesie im najbliższy rok, w: A. Wierzbicki, op. cit., s. 34; zob. też: A. Kownacki, op. cit., s. 20; E. Janiszewski, op. cit., s. 7; A. Kakowski, s. 18; J. Umiastowska z Ostrorogów, op. cit., s. 80; J. Ostromęcka, op. cit., s. 59; I. J. Paderewski, op. cit., s. 18.

112 W. Wiśniewski, Pani..., s. 83.

113 Z. z Rodowiczów Iwanicka, op. cit., s 74.

114 W. Tatarkiewicz wspominał zabawy taneczne odbywane w korytarzu wspólnie ze służbą - pod nieobecność rodziców lokaj grał na skrzypcach, a dzieci z zapałem towarzyszyły pokojówkom i dziewczętom
} 
W części domów ziemiańskich organizowano teatry amatorskie lub żywe obrazy. Bywało, że role w poszczególnych scenach odgrywały także dzieci, a niekiedy teatrzyk w całości przygotowany był przez najmłodszych. Przygotowania do występu, choć często długotrwałe, polegały nie tylko na wyuczeniu się roli, ale także na urządzeniu sceny, wykonania scenografii, strojów, a przy okazji były dobrą zabawą ${ }^{115}$.

Nieodłącznym atrybutem zabaw dziecięcych były i są zabawki. Najmłodsi ziemianie wspominają, że posiadali zabawki tzw. fabryczne, czyli przedmioty specjalnie wykonane w celach zabawowych, najczęściej adresowane do poszczególnych płci. Ich liczba oraz jakość zależna była oczywiście od majętności rodziców. Chłopcy bawili się ołowianymi żołnierzami, strzelbami, pistoletami, łukami z tarczami, kolejkami, konikami (na biegunach, na platformach z kółkami, w postaci figurek), warsztatami. Dziewczynki miały swoje ulubione lalki, wózki, mebelki, statki (naczynia), kolorowe paciorki. Pamiętnikarze wspominają o różnorodnych zabawkach, którymi bawili się i chłopcy i dziewczynki: gumowych piłkach, kołach do serso, blaszanych kogutach, które piały po dmuchnięciu w ogon, drewnianych klockach, loteryjkach, figurkach zwierzątek gospodarskich, welocypedach. Chętnie kupowano też dzieciom książeczki z obrazkami, ilustrowane albumu, bajki, książki do kolorowania, kolorowe ołówki, farby ${ }^{116}$. Zabawki dzieci otrzymywały często z okazji urodzin, imienin, wizyt w mieście czy od przyjezdnych do dworu gości. Anna Gayer przywołuje w swych wspomnieniach otrzymywane od ukochanego wujka zabawki, w tym bąka, który pozostał jej w pamięci na długie lata. Gtośno rozbawiona nie spostrzegłam, że bakk otart się o moja glowe $i$ w taki sposób wplatat się we wlosy, że wyrwat je pozostawiajac na glowie tyse miejsce. Oczywiście krzyczałam z bólu i okropnie płakałam, nie dawałam sie uspokoić. Miałam dopiero 6 lat $^{117}$. Okazją do otrzymywania zabawek było oczywiście Boże Narodzenie, kiedy maluchy z niecierpliwością poszukiwały pod choinką lub poduszką wymarzonych cacek ${ }^{118}$.

Choć dzieci z rodzin ziemiańskich zwykle posiadały zabawki fabryczne, często do zabaw wykorzystywały materiały naturalne, znalezione w najbliższym otoczeniu patyki,

kuchennym w zabawie - najbardziej lubili tańczyć polkę i galopkę, w: T i W. Tatarkiewiczowie, op. cit., s. 23; zob. też: Z. Szymanowska, op. cit., s. 76, 83.

${ }_{115}$ H. Korwin-Milewski, op. cit., s. 32; K. A. Jaworski, op. cit., s. 27-28; Jordan, (J. Wieniawski), op. cit., s. 170; J. z Puttkamerów-Żółtowska, op. cit., s. 47, 48, 52; J. Umiastowska z Ostrorogów, op. cit., s. 80.

116 M. Wańkowicz, op. cit., s. 25, 90; A. Kownacki, op. cit., s. 18; E. Janiszewski, op. cit., s. 8, 23; K. A. Jaworski, op. cit., s. 35; J. Iwaszkiewicz, op. cit., s. 14; M. K. Dziewanowski, op. cit., s. 13; J. Ostromęcka, op. cit., s. 60; W. J. Grabski, op. cit., s. 62, 67; J. z Puttkamerów-Żółtowska, op. cit., s. 14; W. Wiśniewski, op. cit., s. 90.

117 A. Gayer, op. cit., s. 10.

${ }_{118}$ Mialem 4 czy 5 lat, jak pod choinkq znalazłem śliczne koniki o wysokości 20-30 centymetrów, obciqgane prawdziwq skórka z włosiem, w: A. Kownacki, op. cit., s. 18; Jadwiga Ostromęcka pisała: Od Cioci Olgi dostawałyśmy oprócz lalek $i$ ładnych zabawek także wszelkie pomoce naukowe, zeszyty, obsadki, farby, które przybywaty [...] około Świqt Bożego Narodzenia w tajemniczych pakach, w: J. Ostromęcka, op. cit., s. 58; Melchior Wańkowicz wspomniał, jak podezas rozdawania podarunków zachowywali oficjalną radość, ponieważ już na kilka dni wcześniej zwykle udało się dzieciom wyszperać to, co otrzymają. Raz nawet dzięki zdradzie lokaja zdołałam wykraść z szafy i popukać sobie z flinty, która później uroczyście otrzymałem - wspominał po latach, w: M. Wańkowicz, op. cit., s. 37; zob. też: L. Krzywicki, op. cit., s. 80; A. Kownacki, op. cit., s. 18; W. Wiśniewski, op. cit., s. 25; A. Wierzbicki, op. cit., s. 51; M. K. Dziewanowski, op. cit., s. 33; K. Libiszowska-Dobrska, op. cit., s. 23; I. Radliński, op. cit., s. 14; Z. Szymanowska, op. cit., s. 34. 
kamienie, korzenie. Często, na potrzeby zabaw, proste zabawki wykonywali im dorośli, a bardziej zdolne manualnie dzieci samodzielnie z różnych materiałów wykonywały sobie lalki, konie, miecze, łuki, proce, żołnierzy, a nawet stroje ${ }^{119}$. Najmłodsi zbierali też guziki, szpulki, piórka, muszelki, nasiona, szyszki, kolekcjonowali kamienie, minerały czy owady, np. motyle i żuki ${ }^{120}$. Józef Dowbor Muśnicki, wspominał, że fabrycznych zabawek nie miał prawie wcale, gdyż były one drogie i rzadkie (autor urodził się w 1867 r.) - Posiadałem pręty z leszczyny, które pierwotni zastępowaty mi konie, potem dostałem kuca. Szczytem moich marzeń była piszczałka, kogutek [...] kupowana na odpuście parafialnym $^{121}$.

W pamiętnikach dziewczynek nie mogło zabraknąć wspomnień dotyczących zabaw lalkami. Janina z Puttkamerów-Żółtowska wspominała swoje lalki i ulubioną samotną zabawę w ich towarzystwie: Bawiłam się doskonale i najlepiej sama z lalkami [...] nawet wycięte z papieru laki byly mi miłe, wpadałam $w$ rodzaj upojenia urzadzajac dla nich mieszkania $w$ fałdach firanek ${ }^{122}$. Zofia z Rodowiczów-Iwanicka miała codzienny obowiązek, wyznaczony przez bonę, ażeby po wstaniu z łóżka i odmówieniu pacierza uprzatnać pokoik lalek, ubrać lalki $i$ dać im śniadanie - oczywiście na niby ${ }^{123}$. We wspomnieniach Jadwigi Ostromęckiej znajdujemy charakterystykę lalczynych rodzin, wśród których [...] największa powaga cieszyła się pani Olga Tablicka - okazała dama, posiadajaca trzypiętrowe mieszkanie na trzech półkach szafki, z kuchniq na parterze, w której statki były takiej wielkości, że nadawały się $w$ zupetności do gotowania $w$ nich prawdziwych śniadań i obiadów. Tym domem zarzadzała najstarsza nasza siostra i nadawała właściwy tom stosunkom rodzinnym lalek ${ }^{124}$.

Ciekawostką jest, że w nielicznych wspomnieniach pamiętnikarskich nie tylko nie znajdujemy wspomnień dotyczących zabaw dziecinnych, ale wręcz niektórzy z pamiętnikarzy pisali, że nie lubili się bawić, czas spędzali w samotności, na cichej lekturze czy

119 Zofia Szymanowska wspominała uszytego przez mamę kota: Byt ten kot uszyty z jednego kawałka $i$ wypchany watq. Nie byt wykwintny. Byt duży $i$ gruby, z szarego perkalu $w$ czarne prażki. Miat poczciwe oczy z ciemnymi brwiami. Byt wzruszajacy w swojej prostocie i był mój własny, w: Z. Szymanowska, op. cit., s. 39; Andrzej Kownacki samodzielnie zrobił sobie sanki oraz domek do zabawy, w: A. Kownacki, op. cit., s. 26; Wacław Jędrzejewicz z kolegą wylepiali na tekturze całe armie żołnierzy, a Janina z Puttkamerów-Żółtowska wycinała z papieru lalki, w: W. Jędrzejewicz, op. cit., s. 10; J. z Puttkametów-Żółtowska, op. cit., s. 11; Rzecz zabawna - wspominał Wacław Lednicki - mimo iż jeździliśmy już na prawdziwych koniach, wciaż utrzymywaliśmy stajnie dla koni - gatęzi. Stajnie te mieściły się w sadzie, za domem, pod owocowymi drzewami. Każdy z nas miała swojq stajnię. Gdy, jak się czasem okazywało, ogrodnik z ogrodniczymi chtopakami wyrzucali nasze rumaki, oczyszczajac ogród, stawało się to prawdziwa klęska, w: W. Lednicki, op. cit., s. 523; zob. też: I. J. Paderewski, op. cit., s. 19, 33; A. Jaroszewicz, op. cit., s. 25; A. Rostworowski, op. cit., s. 18.

120 Zofia Iwanicka wspominała letnie zabawy z bratem na łonie przyrody, podczas których zbierali motyle i owady, kolekcjonując je w pudełkach, śledzili przemiany poczwarek w motyle, układali zielniki, suszyli zioła, kolekcjonowali kamienie, w: Z. z Rodowiczów Iwanicka, op. cit., s. 65; zob. też: J. Ostromęcka, op. cit., s. 62; J. W. Grabski, op. cit., s. 26; Wspomnienia naszej matki, s. 146; M. Leśkiewicz, op. cit., s. 54; J. Ostromęcka, op. cit., s.62.

121 J. D. Muśnicki, op. cit., s. 17.

122 J. z Puttkamerów-Żółtowska, op. cit., s. 10.

123 Z. z Rodowiczów-Iwanicka, op. cit., s. 69.

124 J. Ostromęcka, op. cit., s. 58. 
w towarzystwie dorosłych. Do takich osób należał np. Stefan Żeromski, który tak charakteryzował swoje dziecięce lata: Co wspominać o latach mojego dzieciństwa? Czyż nie byłem, jak wszystkie dzieci, krzykaczem naprzód małym, potem urwisem, dokuczajacym wszystkim, którego znać w każdym miejscu - o nie... od czasu, jak przyszedtem do tego wieku, że oddano mie do szkót, byłem zawsze samotnym i ponurym. Lubiłem zawsze samotność [...] mogłem obyć się bez towarzystwa nie tylko rówieśników, ale nawet ludzi ${ }^{125}$. Podobnie pisał Antoni Jaroszewicz - Nie lubiłem dokazywać, byłem raczej domatorem unikajacym towarzystwa rówieśników, przesiadywałem $w$ domu, najchętniej czytając ksiażki ${ }^{126}$.

Podsumowując, warto zadać sobie pytanie, czy specyfika narodu polskiego pod jarzmem zaborców wpływała w jakiś sposób na zabawy dziecinne. W pamiętnikach znajdujemy informacje, mówiące o tym, że niektóre z zabaw - również opisanych powyżej, kierowane były wpajanymi przez dorosłych wartościami patriotycznymi, słuchanymi opowieściami czy czytywanymi lekturami. Bawiono się w bitwy o wolność ojczyzny, inscenizowano fragmenty z książek Sienkiewicza, w teatrzykach dziecięcych odgrywano patriotyczne przedstawienia, podczas kinderbali tańczono tańce narodowe. Np. Ignacy Jan Paderewski najbardziej lubił bawić się w żołnierzy - marzył, że uda mu się wyswobodzić ojczyznę: [...] byłem rycerzem dosiadajacym konia-rumaka, na którym wyruszałem po zwycięstwa. Za rumaka stużyt mi długi kij, na którego końcu Antonina umieszczała torbę wypetniona różnymi starymi szmatami, co miało wyobrażać końska głowę - nawet uszy tam byty. Strój mój - mundur polski oraz czerwonq rogatywkę - robiła z białego czerwonego papieru, a dopetnieniem całości byt miecz, wycięty z drzewa moim chłopięcym scyzorykiem. Na tym wspaniałym rumaku hasatem po całym domu, staczajac wyimaginowane boje $e^{127}$.

Dokonana tu analiza pamiętników pozwala stwierdzić, że zabawa w życiu dziecka ziemiańskiego, podobnie jak w przypadku każdego dziecka, miała istotne znaczenie. Choć czasu poświęcanego na swawole w życiu najmłodszych ziemian nie brakowało, to jednak chwile swobodnej i niczym nieskrępowanej zabawy były szczególnie cenne. Dzieci w większości rodzin ziemiańskich otaczane były od najmłodszych lat opieką piastunek, bon, guwernantek, których zadaniem było czuwać nad bezpieczeństwem w każdej chwili dnia, także podczas zabawy. Ta ciąła niemal obecność dorosłych ograniczała niejednokrotnie dziecięcą fantazję i swobodę. Dlatego też wiele dzieci próbowało się pozbyć nadopiekuńczych opiekunek czy opiekunów, próbując ucieczek i chowając się w różnych kryjówkach. A swobodna zabawa dawała okazję nabyć wyjątkowych umiejętności i wiadomości, np. samodzielności, sprawności fizycznej, poznawania świata przyrody, uczenia się na własnych błędach, wytrwałości, konsekwencji, współpracy podczas zabaw z rówieśnikami itp. Im jednak dzieci były starsze, tym więcej pozostawiano im swobody i mniej nadzorowano spędzanie przez nie wolnych od nauki chwil, zupełną niemal swobodę uzyskiwano w momencie rozpoczęcia nauki szkolnej. Przytoczone frag-

\footnotetext{
125 S. Żeromski, op. cit., s. 43.

126 A. Jaroszewicz, op. cit., s. 24.

127 I. J. Paderewski, op. cit., s. 33-34.
} 


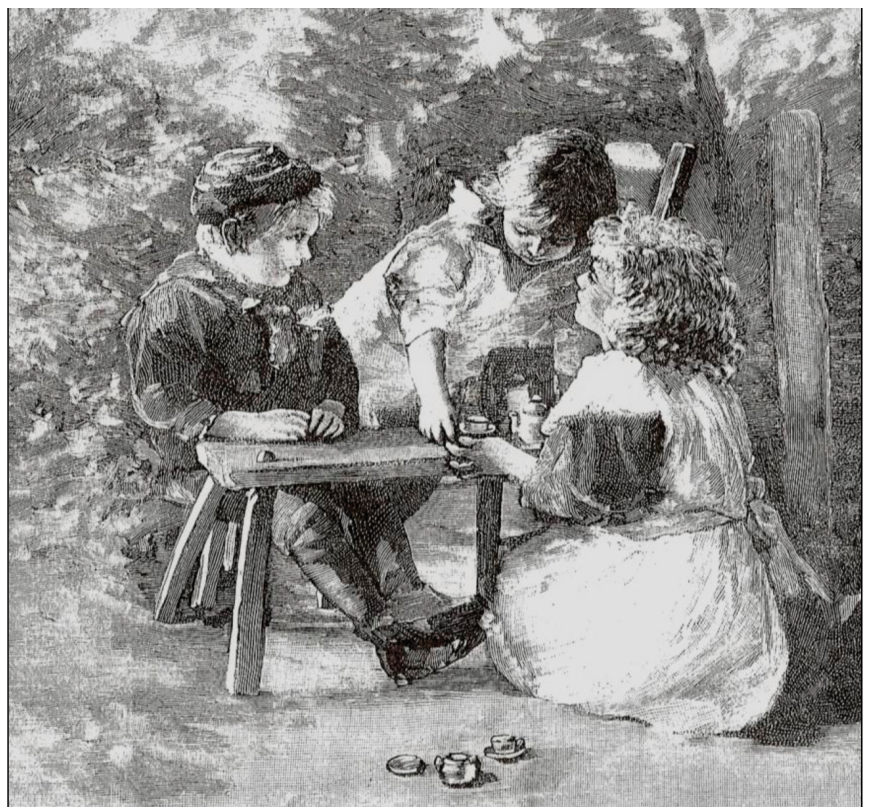

Zabawa po nauce, „Przyjaciel Dzieci” 1893, nr 44

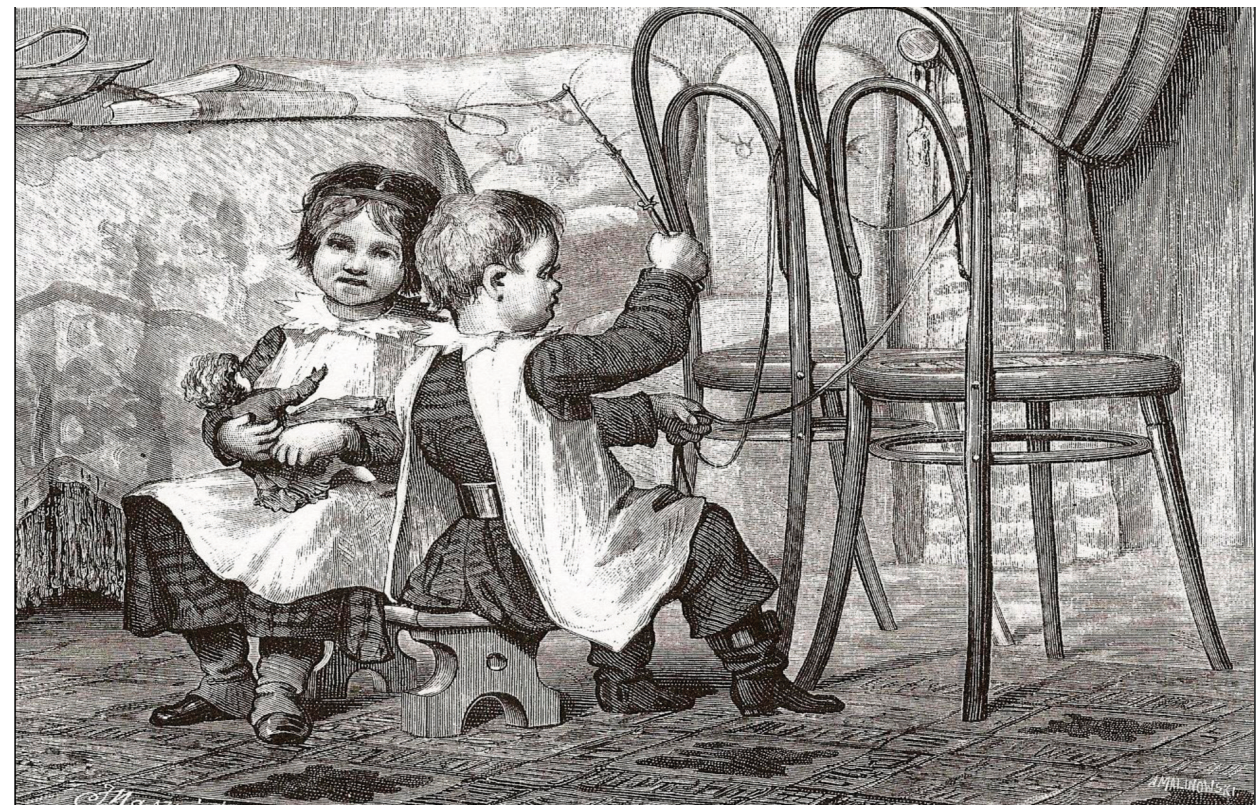

Jazda!..., kopia obrazu J. Maszyńskiego, „Tygodnik Ilustrowany” 1875, nr 386 


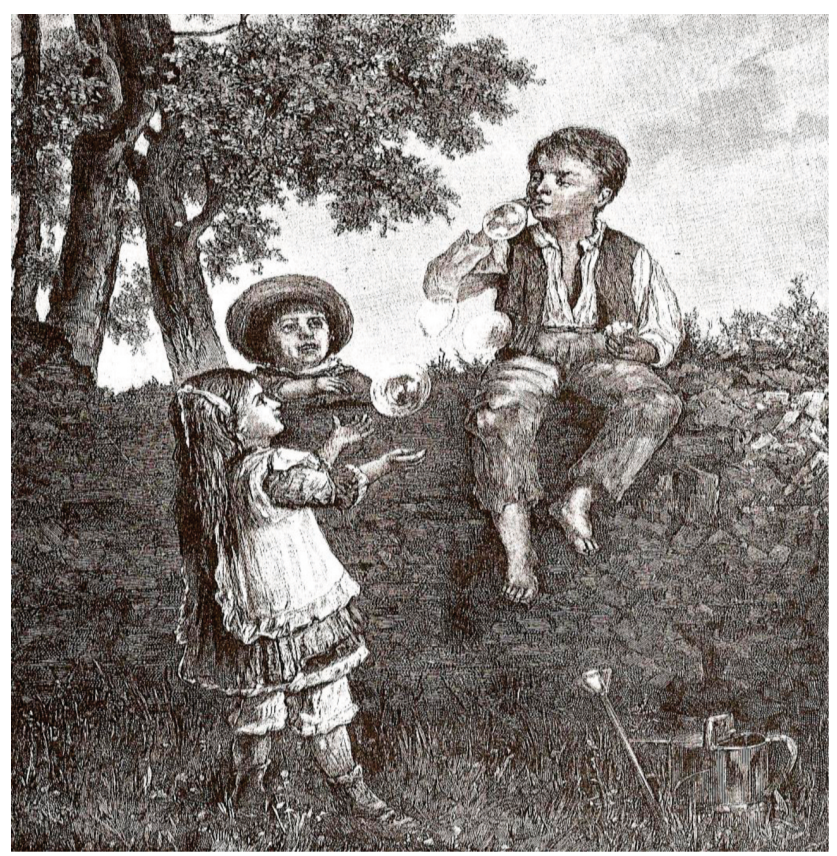

Bański mydlane, rys. E. Perle, ryt. E. Gorazdowski, „Kłosy” 1875, nr 45

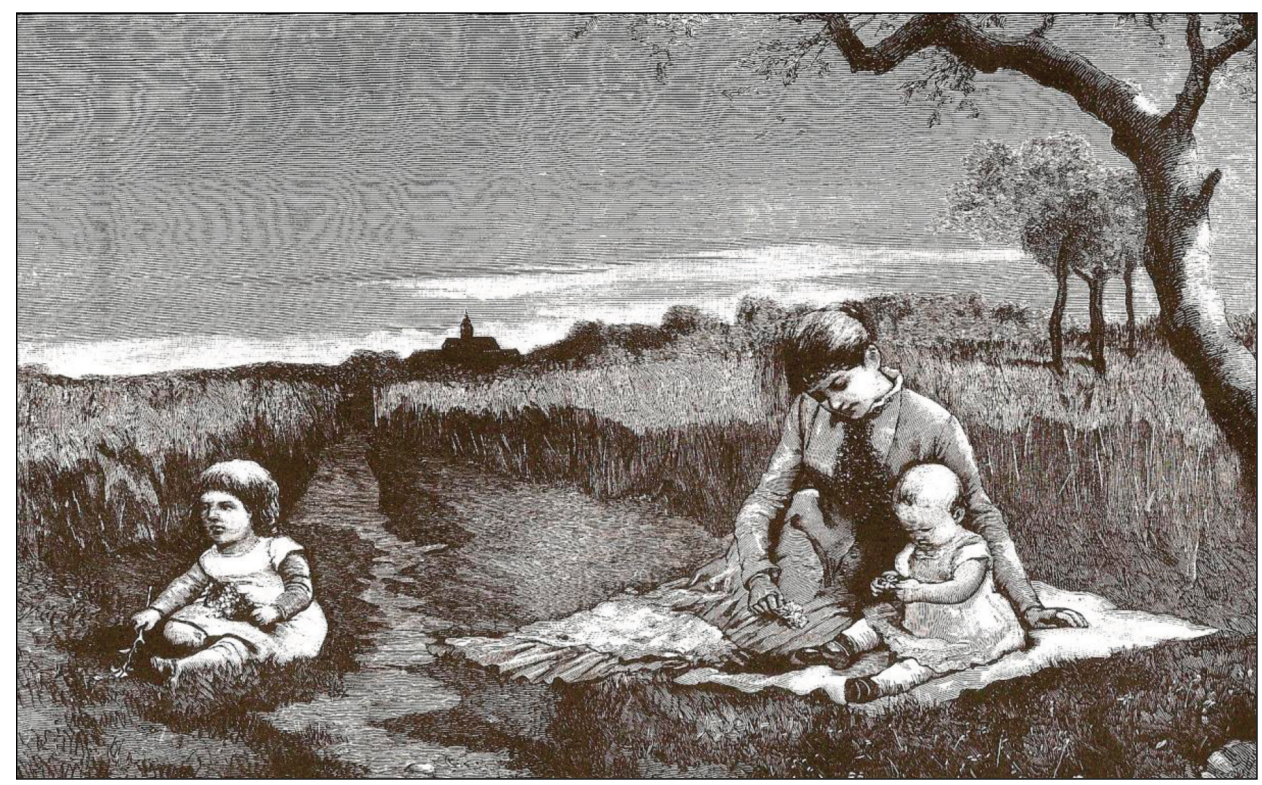

Zabawa kwiatowa, obraz A. Malinge`a, „Biesiada Literacka” 1893, nr 27 
menty pamiętników pokazują, że szczególnie w pamięci ziemian zapadły swobodne zabawy na powietrzu. Ogród, park, zabudowania gospodarskie, otoczenie dworu - lasy, łąki, zbiorniki wodne dawały mnóstwo okazji do zabaw, a liczne zadrapania, siniaki, czy nawet poważniejsze wypadki nie zniechęcały do dalszych figli i harców. Wśród zabaw na powietrzu przeważały zabawy ruchowe - w wojnę, ganianego, chowanego, wspinanie się po drzewach, kąpiele, spacery itp. Najczęściej dzieci bawiły się w towarzystwie rówieśników - rodzeństwa czy dzieci z otoczenia dworu - niewiele jest wspomnień, mówiących o czynnym zaangażowaniu dorosłych w zabawy. Rolą dorosłych - rodziców, bon, guwernerów było zorganizowanie dzieciom czasu, dozór podczas zabawy i ewentualnie ratowanie z opresji, kiedy zabawa stawała się niebezpieczną. Nie dziwi bogactwo zabaw i pomysłowość dzieci w zakresie ich realizacji - przestrzeń dworu zarówno jego wnętrze, jak i otoczenie oraz naśladownictwo stosunkowo bogatego w wrażenia świata, w jakim obracały się dzieci ziemiańskie doskonale inspirowały najmłodszych do zabawy. 
